\title{
Fatigue Crack Growth Evaluation of IMO Type B Spherical LNG Cargo Tank Considering the Effect of Stress Ratio and Load History
}

\author{
Stress Ratio 및 Load History 효과를 고려한 \\ IMO Type B Spherical LNG Cargo Tank 피로 균열진전 평가 \\ Myung-Sup Lee,** and Myung-Hyun Kim*,† \\ *Material Strength Lab of Naval Architecture \& Ocean Engineering, Pusan National University, \\ Busan, 46241, Korea \\ **Hyundai Heavy Industries, Ulsan, 44032, Korea
}

†Corresponding author: kimm@pusan.ac.kr

(Received July 30, 2021; Revised August 30, 2021; Accepted September 27, 2021)

\begin{abstract}
The crack propagation on a spherical IMO Type B LNG tank deployed on a 150K class LNG carrier is studied. IMO Type B tanks require a high level of safety . Therefore, analyses such as strength evaluation, fatigue analysis, fatigue crack propagation analysis, and LNG leak rate should be conducted to ensure safety . Various fatigue crack growth models were proposed for fatigue crack propagation analysis. The Forman model and the Walker model consider the stress ratio. Furthermore, the Huang model, and the Lee and Kim model consider the stress ratio and the effects of overload and underload present in the past load history on crack propagation.

To examine the effects of stress ratio and load history for the fatigue crack propagation models, the crack growth of the LNG tank was evaluated by considering the stresses under full load and ballast load operating conditions, and three stress amplitude sequence cases.
\end{abstract}

Key Words: IMO Type B Tank, Fatigue crack growth, Variable amplitude fatigue, Load history, Stress ratio

\section{Introduction}

Owing to recent environmental problems, natural gas has attracted much attention as eco-friendly fuel in the intermediate stage of conversion into green energy sources, such as hydrogen and ammonia, which can reduce the emission of sulfur oxides, nitrogen oxides, and carbon dioxide. Natural gas is transported as liquefied natural gas (LNG) that can reduce the volume to $1 / 600$ to improve transport efficiency. For the liquefaction of natural gas, it is maintained at $-163^{\circ} \mathrm{C}$ under the atmospheric pressure. To transport such cryogenic and dangerous cargo, LNG cargo holds must be designed in accordance with IMO IGC Code ${ }^{1)}$.

IMO classifies cargo holds mainly into independent and integrated tanks according to the connection with the hull structure as shown in Fig. 1. Independent tanks

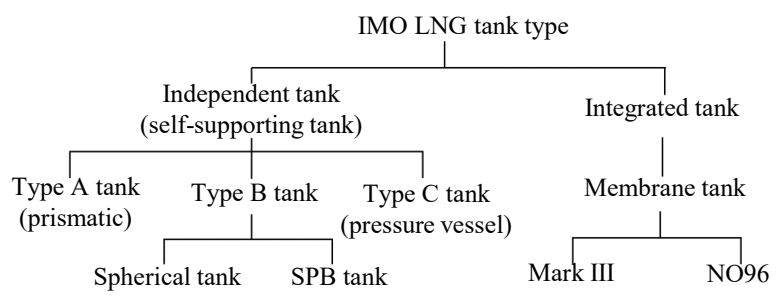

Fig. 1 IMO classification of LNG containment system

are again divided into Type A, B, and C tanks according to the type of the secondary barrier that can store LNG for 15 days of movement to a nearby port when the primary barrier is damaged during a voyage. The Type B tank, which is the target of this study, will be described later. In the case of the Type A tank, it must be equipped with a full secondary barrier. The hull structure that surrounds the tank is utilized as the secondary barrier and must be built using materials that 
can withstand low temperatures. The Type A tank is usually applied to vessels whose hulls are exposed to relatively high temperatures $\left(-55^{\circ} \mathrm{C}\right)$, such as liquefied petroleum gas (LPG) carriers. In the case of the Type C tank, high safety must be secured through an increase in design pressure as well as internal pressure and nondestructive tests in the production stage so that no secondary barrier is required. To withstand high pressure, cylindrical or Bi-Lobe type pressure vessels are commonly used. Integrated tanks are directly connected to the hull structure (Mastic Bonding). They consist of membrane-type primary and secondary barriers to withstand the hull behavior and internal LNG load, and GTT's Mark III and NO96 systems are commonly used.

The Type B tank, which is the target of this study, is equipped with a partial secondary barrier that is referred to as a drip tray. The partial secondary barrier is allowed for the Type B tank because the "leak before failure" concept is applied through the extensive analysis of the $\operatorname{tank}^{2,3)}$. In other words, the Type B tank must not be subjected to fatigue failure through fatigue analysis and fatigue crack growth (FCG) analysis. Even if a fatigue crack occurs, the LNG leaked through the fatigue crack must be collected in the drip tray through the leakage path between the tank and the insulation material, and the drip tray must be designed in a size that can store the leaked LNG for 15 days to secure the safety of the vessel. The Type B tank has been used for LNG carriers and as the LNG fuel tank as it does not exhibit the sloshing problem that occurs during the partial filling of cargo along with high strength and reliability $^{4)}$.

In this study, research was conducted on the crack growth of Type B spherical tanks, which have been built in large quantities in South Korea. The effects of the stress ratio and load history were examined using various crack growth analysis models.

\section{LNG Tank Strength Evaluation}

\subsection{Overview of $150 \mathrm{~K}$-class $L N G$ carrier}

In the LNG carrier, four cargo tanks in the same size are arranged as shown in Fig. 2. Each cargo tank consists of a tank insulation panel that surrounds the tank,

Table 1 Ship principal dimensions

\begin{tabular}{|c|c|}
\hline Item & Dimension (m) \\
\hline Length & 277 \\
\hline Breadth & 48.9 \\
\hline Depth & 23.35 \\
\hline
\end{tabular}

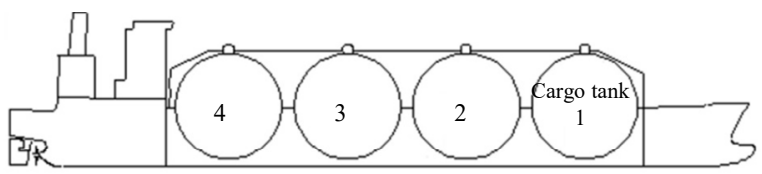

(a) Hull profile configuration ${ }^{5)}$

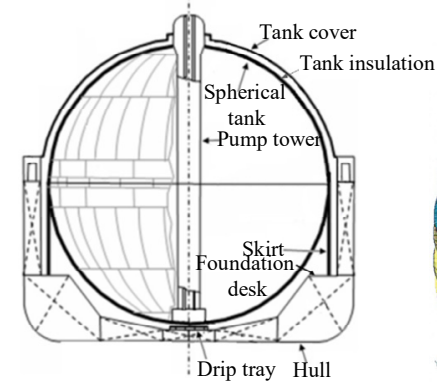

(b) Hull section configuration ${ }^{5}$

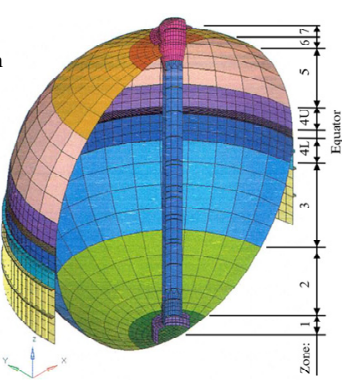

(c) Tank zone
Fig. 2 Hull profile, section and tank zone configuration

a tank cover that surrounds the tank and insulation material, a pump tower in which an LNG pump and pipelines are installed, a skirt and a foundation desk that connect the equator of the tank to the hull, and a drip tray that collects the leaked LNG. Each tank has eight zones with different thicknesses, including the equator, depending on the vertical location.

\subsection{LNG tank strength evaluation procedure}

The tank strength must be evaluated first to calculate the stress to be applied to the crack growth of the spherical LNG tank, and several analysis procedures are required. First, the wave load and the acceleration of each tank are calculated through hydrodynamic analysis under various cargo loading conditions and applied to the structural analysis of the tank. Loads that are applied to the structural analysis include static/dynamic loads by loaded cargo including LNG and the weight of the hull, internal/external vapor pressures, thermal distribution and thermal stress by the temperature difference between cryogenic LNG and the outside air at room temperature, and the hull interaction load. Once the thickness of the tank is determined through yield and buckling strength evaluation, the size of the drip tray is determined by calculating the LNG leak rate after conducting fine mesh analysis for the tank, skirt, or pump tower joints; buckling strength evaluation for the skirt; pump tower strength evaluation in consideration of sloshing; fatigue analysis for evaluating initial cracking; and crack growth analysis for calculating the crack growth rate $^{2)}$. Fig. 3 shows the full ship finite element analysis (FEA) model used for analysis and the shape of the cargo hold deformed by the hull girder bending moment. 


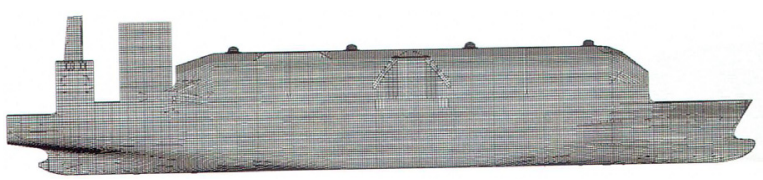

(a) Full ship FEA model

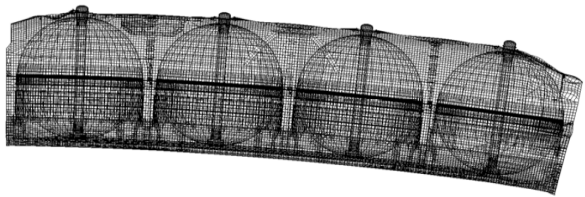

(b) Cargo hold deformed shape by vertical hogging bending moment $^{5)}$

Fig. 3 Full ship FEA model and cargo hold deformed shape by vertical hogging bending moment

\section{FCG Analysis and Model Comparison}

\subsection{FCG}

In general, the Paris model shown in equation (1) is used to evaluate the crack growth behavior, which is expressed using the relationship between the stress intensity factor $(\Delta \mathrm{K})$ and the crack growth rate $(\mathrm{da} / \mathrm{dN})$ as shown in Fig. 4.

$$
\frac{d a}{d N}=C(\triangle K)^{m}
$$

where $\mathrm{a}$ is the crack size, $\mathrm{N}$ is the number of loads, and $\mathrm{C}$ and $\mathrm{m}$ are material constants.

Classification societies, such as $\mathrm{LR}^{2)}$ and $\mathrm{DNV}^{3)}$, follow British Standard BS7910 ${ }^{7)}$ to calculate the stress intensity factor $(\Delta K)$ as shown in equation (2). BS7910 uses the Newman-Raju method ${ }^{8)}$ that considers the combination of the membrane stress and bending stress to calculate $Y \Delta \sigma$ of the elliptical surface defect as shown in equation (3).

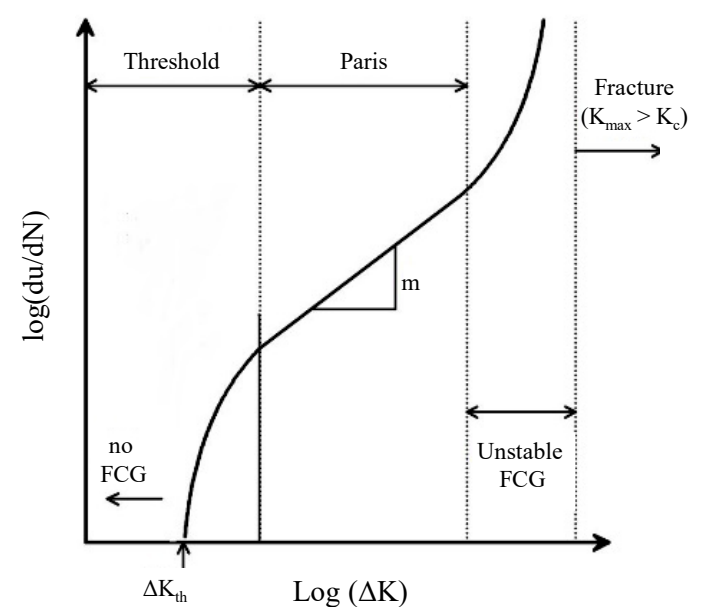

Fig. 4 Schematic of typical FCG data ${ }^{6}$

$$
\begin{aligned}
& \triangle K=Y \triangle \sigma \sqrt{\pi a} \\
& Y \triangle \sigma=\left[M_{k m} \Delta \sigma_{m}+H M_{k b} \Delta \sigma_{b}\right] F / \varnothing
\end{aligned}
$$

where $\mathrm{Y}$ is the shape function, $\Delta \sigma$ is the stress amplitude, $\Delta \sigma_{\mathrm{m}}$ is the membrane stress amplitude, $\Delta \sigma_{\mathrm{b}}$ is the bending stress amplitude, $\mathrm{M}_{\mathrm{km}}$ and $\mathrm{M}_{\mathrm{kb}}$ are the membrane and bending stress concentration factors at the weld toe, $\mathrm{H}$ is the ratio between the membrane and bending stress concentration factors, $\mathrm{F}$ is a function of the crack geometry and thickness, and $\phi$ is the elliptic function for crack geometry ${ }^{7}$.

\subsection{FCG models}

Since the Paris model cannot reflect the actual crack growth as it does not consider various stress ratios and load history that are applied to the actual structure, various crack growth models have been proposed.

First, models that consider the stress ratio (R), which represents the ratio between the maximum and minimum stresses, are as follows ${ }^{9)}$. Walker ${ }^{10)}$, Eason et al. ${ }^{11)}$, and Kurihara et al. ${ }^{12)}$ expressed the stress ratio in the form of $\Delta K_{e f f}=f(R) \Delta K$ or $\Delta K_{e f f}=K_{\max }^{(1-r)} \Delta K^{r}$ as shown in equation (4) to reflect the accelerated crack growth when the stress ratio increases.

$$
\frac{d a}{d N}=\frac{C_{0}}{(1-R)^{m(1-r)}}(\Delta K)^{m}
$$

where $r$ is the material constant.

Forman $^{13)}$ and McEvily and Gregor ${ }^{14)}$ added the fracture toughness $\left(\mathrm{K}_{\mathrm{C}}\right)$ or the maximum stress intensity factor $\left(\mathrm{K}_{\max }\right)$ to the Paris model as shown in equation $(5)^{9)}$. The second equation shows that the crack growth rate increases as the $\mathrm{K}_{\max }$ value approaches $\mathrm{K}_{\mathrm{c}}{ }^{15}$.

$$
\frac{d a}{d N}=\frac{C(\Delta K)^{m}}{(1-R) K_{c}-\Delta K}=\frac{C(\Delta K)^{m}}{(1-R)\left(K_{c}-K_{\max }\right)}
$$

Huang and Moan $^{16)}$ proposed a model by adjusting various stress intensity factor values that occurred in test results with different stress ratios using the test results of $\mathrm{R}=0$ as shown in equation (6), and a model that considers both the stress ratio correction factor $\left(M_{R}\right)$ and the plastic region size correction factor $\left(\mathrm{M}_{\mathrm{P}}\right)$, which explains the delay in crack growth by overload, as shown in equation $(7)^{17)}$.

$$
\begin{aligned}
& \frac{d a}{d N}=\left[\left(\Delta K_{e q 0}\right)^{m}-\left(\Delta K_{t h 0}\right)^{m}\right] \\
& \triangle K_{e q 0}=M_{R} M_{P} \Delta K
\end{aligned}
$$

Lee and $\mathrm{Kim}^{18)}$ introduced the load history correction 
factor $\left(\mathrm{M}_{\mathrm{H}}\right)$ that can consider underload as well as overload using Port's empirical formula ${ }^{19)}$ based on the Huang model as shown in equation (11) and proposed a crack growth model as shown in equation (8). This model applied exponential weights for the stress ratio correction factor $\left(\mathrm{M}_{\mathrm{R}}\right)$ and load history correction factor $\left(\mathrm{M}_{\mathrm{H}}\right)$ by comparing various tests that could be found in the literature as shown in equations (9) to (11).

$$
\begin{aligned}
& \frac{d a}{d N}=C\left(\Delta K_{e q}\right)^{m} \\
& \Delta K_{e q}=M_{R}^{1.1} M_{H}^{0.9} \Delta K \\
& M_{R}=\left\{\begin{array}{cc}
\left(1-R_{1}\right)^{-\beta_{1}} & \left(-5 \leq R_{1}<0\right) \\
\left(1-R_{1}\right)^{-\beta} & \left(0 \leq R_{1}<0.5\right) \\
\left(1.05-1.4 R_{1}+0.6 R_{1)^{-\beta}}^{2}\right. & \left(0.5 \leq R_{1}<1\right)
\end{array}\right. \\
& M_{H}=\left(12.65 e^{\left.-2.54 R_{2}\right)^{1 / m}}\right.
\end{aligned}
$$

where,

$$
\begin{aligned}
& R_{1}=\text { Stress ratio } \\
& \begin{aligned}
R_{2} & =\frac{K_{O L}-K_{U L}}{K_{\max }-K_{U L}} \\
\beta & =0.5 \text { for titanium alloy } \\
& =0.7 \text { for aluminum alloys and steels } \\
\beta_{1} & =1.2 \beta
\end{aligned}
\end{aligned}
$$

$\mathrm{K}_{\mathrm{OL}}, \mathrm{K}_{\mathrm{UL}}, \mathrm{K}_{\max }$ : Stress intensity factor for overload, underload and maximum load

\subsection{FCG analysis for the spherical LNG tank}

Fig. 5 shows the stress amplitudes and positions applied in crack grown evaluation through the LNG tank strength evaluation described above. The membrane and bending stress amplitudes in the weld zone between Zone 2 and Zone 3, which had a relatively high stress amplitude and a wide range, were evaluated to be 40 and $2.5 \mathrm{MPa}$, respectively. In addition, the static stresses under the full load and ballast operating con-

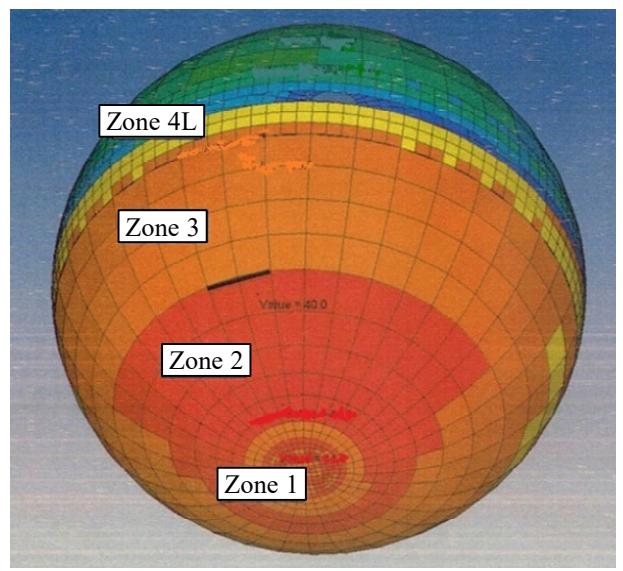

Fig. 5 Stress range of circumferential detail

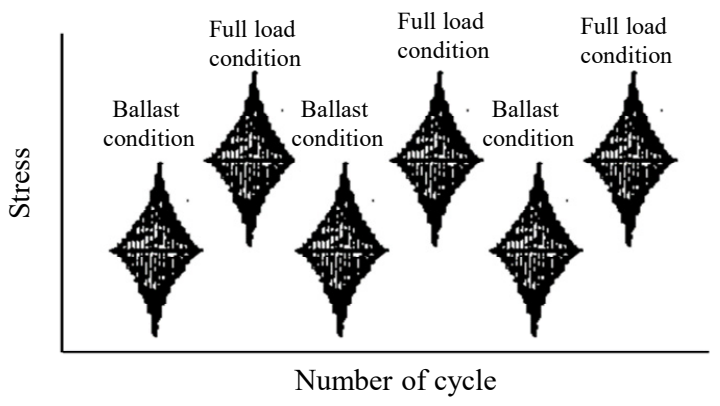

Fig. 6 Schematic diagram of stress

Table 2 Material property for AL5083-O

\begin{tabular}{|c|c|c|}
\hline $\begin{array}{c}\mathrm{C} \\
(\mathrm{mm} / \mathrm{cycle})\end{array}$ & $\begin{array}{c}\mathrm{m} \\
(M P a \sqrt{m m})\end{array}$ & $\begin{array}{c}\text { Kth } \\
\left(M P a ~ m m^{3 / 2}\right)\end{array}$ \\
\hline $1.536 \mathrm{E}-12^{21)}$ & $3.04^{21)}$ & $24.3^{22)}$ \\
\hline
\end{tabular}

ditions were calculated to be 42.5 and $2.0 \mathrm{MPa}$, respectively. Fig. 6 shows a schematic diagram for the stress history applied to the vessel.

As for the size of the initial surface defect, a depth (a) of $0.5 \mathrm{~mm}$ and a length (2c) of $50 \mathrm{~mm}$ were applied in accordance with the non-destructive testing (NDT) acceptable standards of a shipyard ${ }^{20)}$.

Table 2 shows the crack growth-related material properties of the aluminum alloy (5083-O) used to build the tank.

The stress intensity factor $(\Delta \mathrm{K})$ can be calculated using an empirical formula obtained through tests ${ }^{23)}$ and an analytical method ${ }^{24)}$, but it was calculated in this study using equation (3) according to BS7910 ${ }^{7}$ Annex $M$ for a surface defect as shown in Fig. 7. In addition, the stress concentration factor according to the construction tolerance of LR Procedure ${ }^{2)}$ Section D12 was considered.

In this study, the membrane stress distribution shown in Fig. 8 was applied by assuming the long term waveinduced stress range spectrum that encounters the North Atlantic wave $10^{8}$ times and 1.0 for the Weibull distribution shape function, $h$, in accordance with the DNV Guideline ${ }^{3)}$. In addition, the cases of exposure to

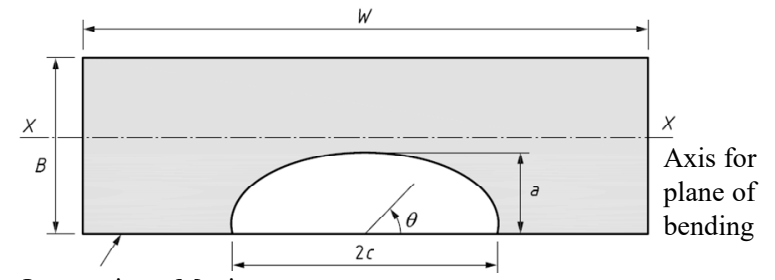

In equations, Maximum tensile bending stress is at this surface

Fig. 7 Surface flaw $^{7}$ 


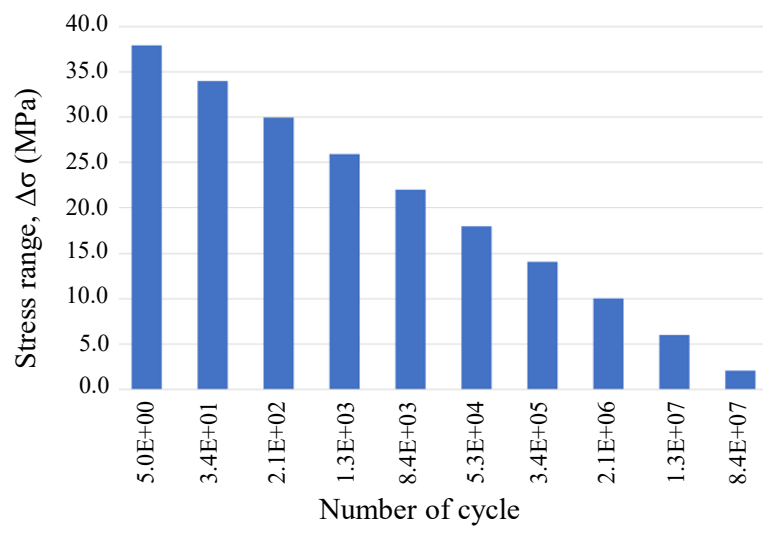

Fig. 8 Long term membrane stress distribution $\left(10^{8}\right.$ cycles $)$

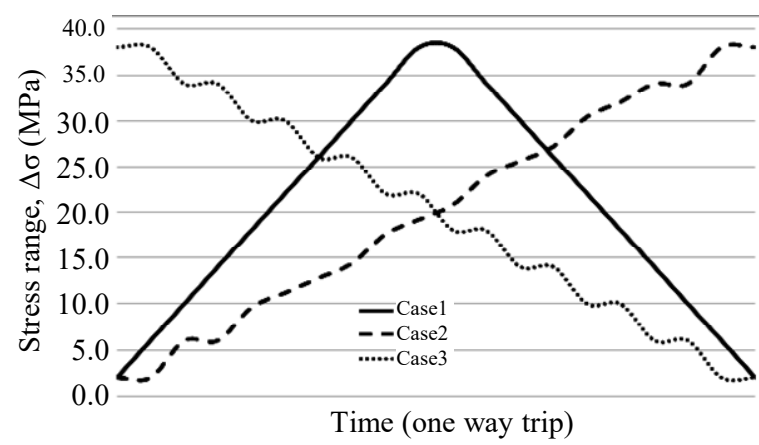

Fig. 9 Membrane stress range history during one way trip $\left(2 \times 10^{5}\right.$ cycles $)$

three stress amplitude sequences during a one-way trip were evaluated to examine the influence of the change in load history on crack growth as shown in Fig. 9. For Case 1, a general distribution in which small loads are applied in coastal waters and large loads in the distant sea during operation was assumed. For Case 2 and Case 3 , the load increased or decreased during operation. Under the condition of performing 500 voyages during the service life of the vessel, the stress distribution of one voyage was assumed to be $2 \times 10^{5}$ cycles.

\section{Results and Discussion}

Fig. 10 shows the results of applying five crack growth models and three load histories to the IMP Type B spherical LNG tank. In the Forman model, the crack depth "a" exceeded $22.5 \mathrm{~mm}$, which corresponds to the crack depth criterion of $0.5 \mathrm{t}$ at $6.0 \mathrm{E}+07$ cycles. Overall, the Forman and Paris models exhibited conservative results while the Huang model showed the most optimistic results. The Lee \& Kim model exhibited relatively optimistic results in a similar manner to the Walker model. The Forman and Walker models consider the stress ratio as shown in equations (4) and (5). In the case of the Walker model, the crack growth rate ac-

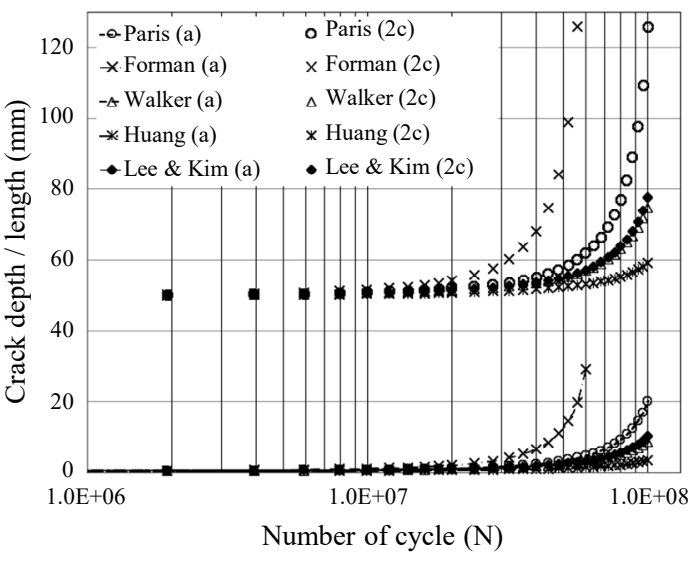

(a) Case 1

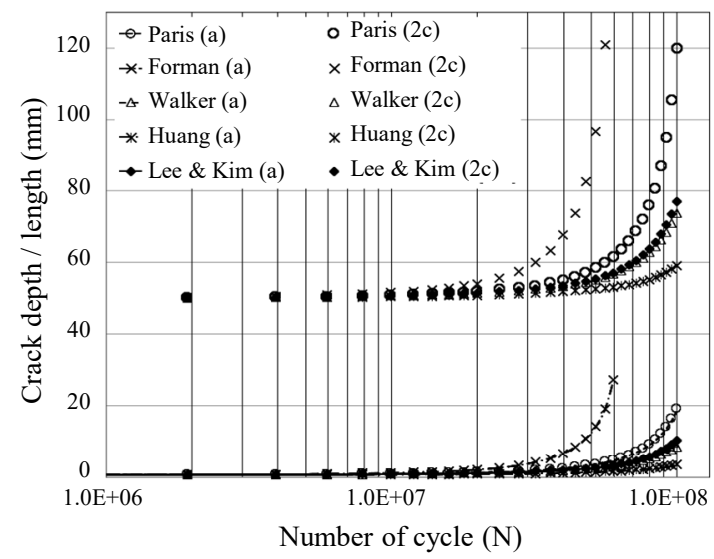

(b) Case 2

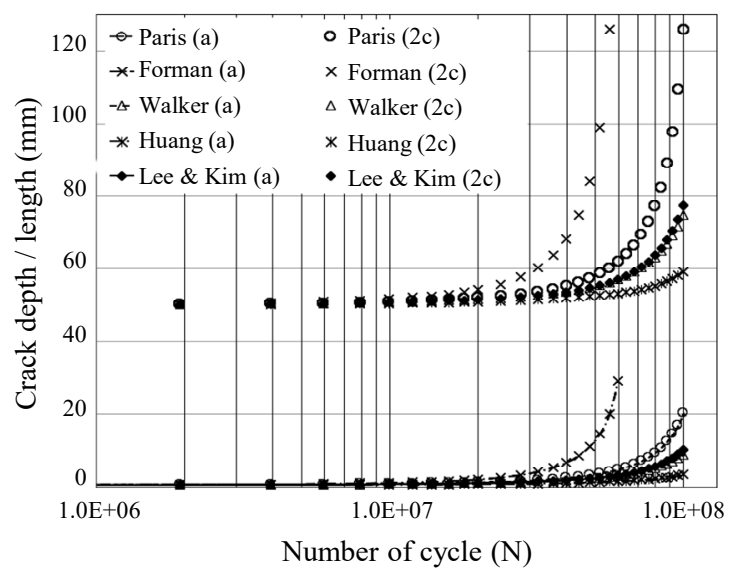

(c) Case 3

Fig. 10 Results of fatigue crack growth for depth ' $a$ ' and length ' $2 \mathrm{c}$ '

cording to the increase in stress ratio was evaluated to be slower compared to the Forman model because $m$ is used as an exponent for the stress ratio.

Fig. 11 shows the detailed results of crack growth for $1.0 \mathrm{E}+6$ to $1.0 \mathrm{E}+7$ cycles in Case 1 . All models, except for the Paris model, exhibited stepwise increases in crack growth rate as the number of cycles increased. This indicates an increase in crack growth rate under 


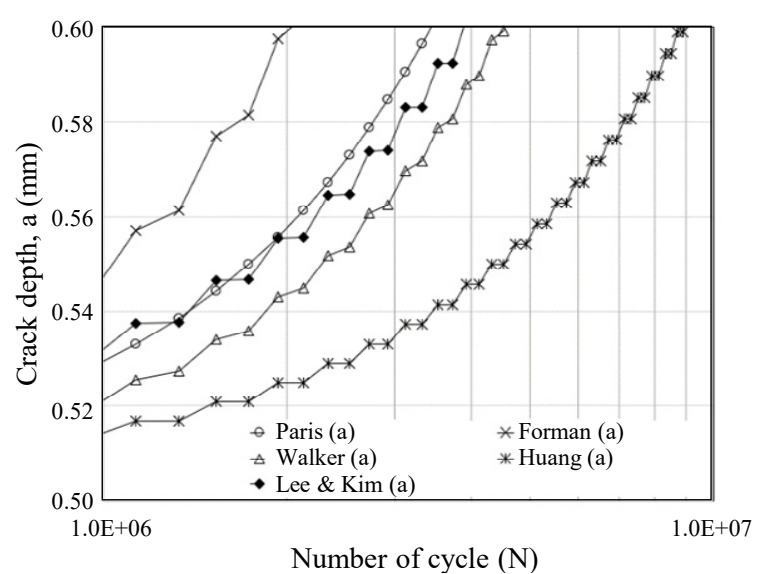

(a) Depth 'a' for 1.0E+06 1.0E+07 Cycles

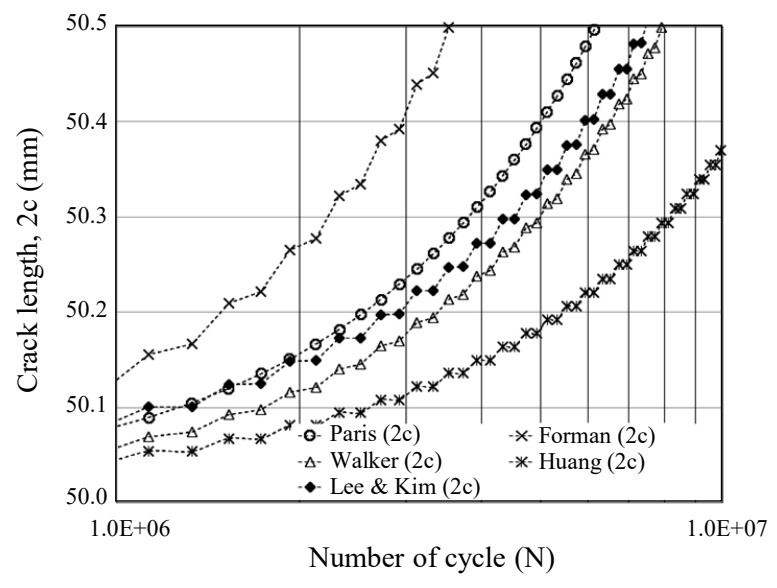

(b) Length ' $2 \mathrm{c}$ ' for 1.0E+06 1.0E+07 Cycles

Fig. 11 Detail results of fatigue crack growth for case 1

the full load condition and a reduction in crack growth rate under the ballast operating condition. Meanwhile, the Huang model and the Lee \& Kim model, which consider both the stress ratio and load history, clearly show the process in which crack growth is accelerated under the full load condition and decelerated under the ballast operating condition ${ }^{25)}$. In the case of the Huang model, the lowest crack growth rate was observed as shown in Fig. 11 because the weakening of the cracking delay by overload ${ }^{26,27)}$ cannot be reflected when underload is applied after overload in the past load history unlike the Lee \& Kim model.

To compare the influence of the three load history cases, the crack growth results for each model are shown in Fig. 12. The Paris, Forman, and Walker models showed no significant difference despite the difference among the three load history cases. In the Huang model that considered the plastic region size correction factor $\left(\mathrm{M}_{\mathrm{P}}\right)$ and the Lee \& Kim model that introduced the load history correction factor $\left(\mathrm{M}_{\mathrm{H}}\right)$, the slowest crack growth was observed in Case 3 where the load continuously decreased during operation and the highest crack growth rate in Case 2. The crack growth rate varies depending on the probability of the occurrence of overload in the past. For Case 3, the delay in crack growth continuously occurs because overload is always present in the load history.

\section{Conclusion}

In this study, research was conducted on the crack growth of the IMP Type B spherical LNG tank placed in a $150 \mathrm{~K}$-class liquefied natural gas (LNG) carrier. The effects of the stress ratio and load history were examine using various crack growth analysis models.
In the case of the IMO Type B tank, fatigue analysis, fatigue crack growth (FCG) analysis, and the calculation of the LNG leak rate are necessary in addition to strength evaluation because a high level of safety is required through various analyses. Various models other than the Paris model have been proposed for FCG analysis. The Forman and Walker models consider the stress ratio, whereas the Huang model and the Lee \& Kim model consider the influence of the presence of overload and underload in the past load history on crack growth as well as the stress ratio.

The FCG of the LNG tank was evaluated considering the stress under full load and ballast operating conditions and three stress amplitude sequence cases to examine the effects of the stress ratio and load history for five crack growth models, and the following conclusions were drawn.

1) The Paris model that shows conservative results does not consider the stress ratio and load history, and it has been used in actual ship design through the rules of classification societies and international standards.

2) The Forman and Walker model that consider the stress ratio generally show conservative results, but the results are different depending on the method of applying the stress ratio. Neither of them considers the effect of the load history.

3) The Huang model reflects a reasonable stress ratio, but shows optimistic results because it cannot reflect the reduction in the crack growth delay of overload by underload.

4) The Lee \& Kim model is applicable in actual design because it considers the load history by underload as well as overload and shows results close to those of the Paris model. 


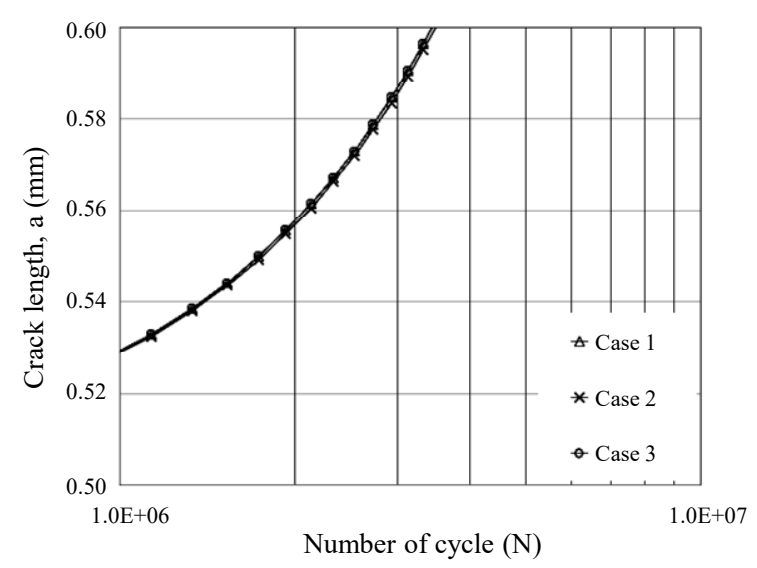

(a) Paris model

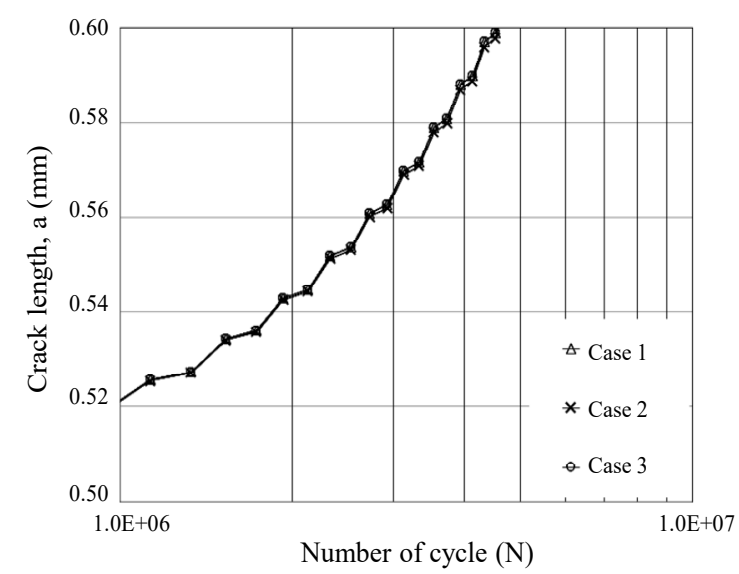

(c) Walker model

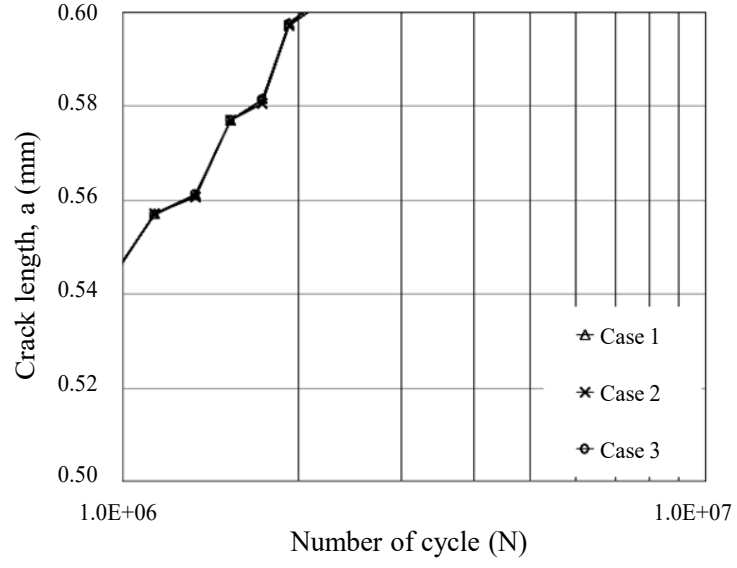

(b) Forman model

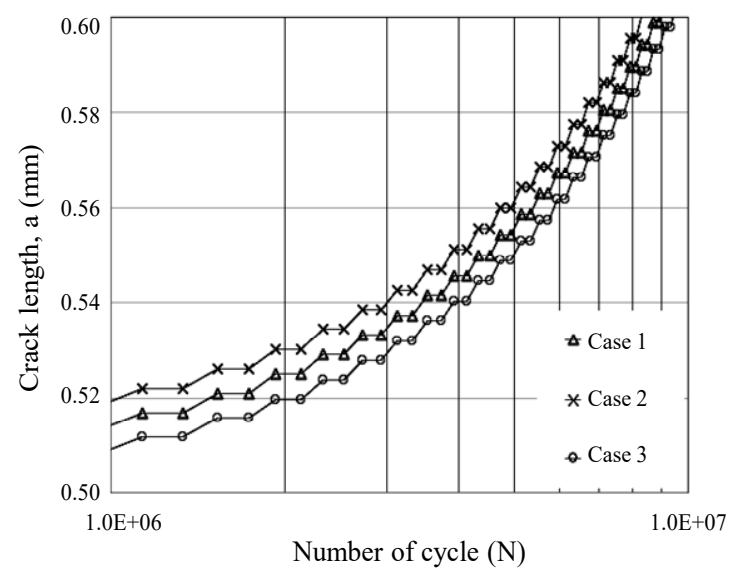

(d) Huang model

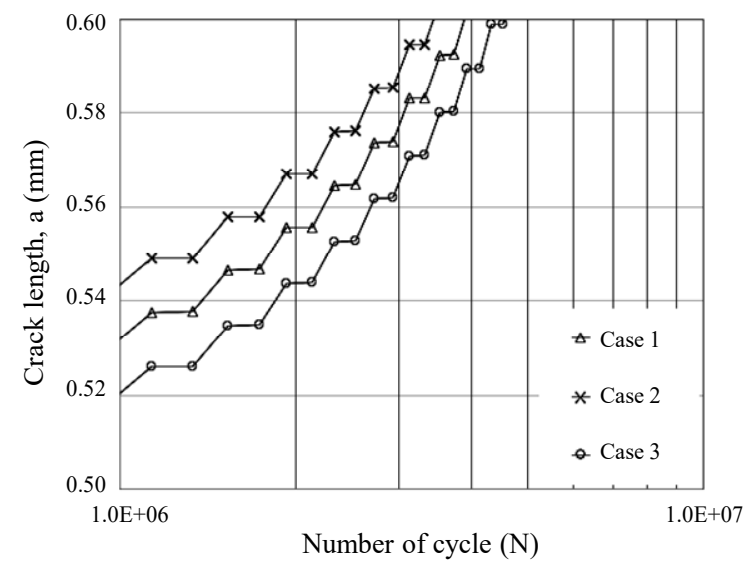

(e) Lee \& Kim model

Fig. 12 Fatigue crack growth of cases $1 \sim 3$ for $1.0 \mathrm{E}+06 \sim 1.0 \mathrm{E}+07$ cycles

ORCID: Myung-Sup Lee:https://orcid.org/0000-0003-2661-8960 ORCID: Myung-HyunKim:https://orcid.org/0000-0003-4428-6058

\section{References}

1. IMO, The International Code of the Construction and Equipment of Ships Carrying Liquefied Gases in Bulk (IGC Code), Imternational Maritime Organizqation
Resolution MSC. 370(93) (2014).

2. LR, Fatigue assessment of ship units adopting IMO Type $\mathrm{B}$ independent tanks constructed primarily of plane surfaces for the storage of liquefied gases, Lloyd's Register ShipRight Design and construction, (2014).

3. DNV GL, Liquefied gas carriers with spherical tanks of type B, DNV GL DNVGL-CG-0134 (2018).

4. Y. Nagata, IHI-SPB Tank for LNG-Fueled Ship, IHI 
Engineering Review, 2 (2015).

5. U. N. Kim, A Study on the Buckling Strength of the Skirt Structure in the Spherical LNG Carriers, J. Soc. Naval Archit. Korea, 54 (2017) 393-405. https://doi.org/10.3744/SNAK.2017.54.5.393

6. J. A. Newman, The Effects of Load Ratio on Threshold Fatigue Crack Growth of Aluminum Alloys, Virginiatech Doctor Dissertation, (2000).

7. BS7910, Guide to methods for assessing the acceptability of flaws in metallic structures, British Standards, (2013).

8. J. C. Newman Jr and I. S. Faju, Analyses of surface cracks in finite plates under tension or bending loads, NASA Technical Report, 1578 (1979).

9. A. Chahardehi and A. Mehmanparast, Fatigue crack growth under remote and local compression - a state-of- the-art review, Frattura ed Integrità Strutturale, 35 (2016) 41-49.

https://doi.org/10.3221/IGF-ESIS.35.05

10. K. Walker, The effect of stress ratio during crack propagation and fatigue for 2024-T3 and 7075-T6 aluminum, ASTM STP462, (1970).

11. E. D. Eason, J. D. Gilman, D. P. Jones, and S. P. Andrew, Technical basis for a revised fatigue crack growth rate reference curve for ferritic steels in air, J. Press. Vessel Technol. 114 (1992) 80-86. https://doi.org/10.1115/1.2929016

12. M. Kurihara, A. Katoh, and M. Kawahara, Effects of stress ratio and step loading on fatigue crack propagation rate, Soc. Mater. Sci. 1 (1985) 217-233.

13. R. G. Forman, Study of fatigue crack initiation from flaws using fracture mechanics theory, Eng. Fract. Mech. 4 (1972) 333-345. https://doi.org/10.1016/0013-7944(72)90048-3

14. A. J. McEvily and J. Gregor, On the threshold for fatigue-crack growth, 4th International Conference of Fracture, Waterloo, 2 (1977) 1293-1298.

15. N. E. Dowling, Mechanical Behavior of Materials, Pearson, (2013) 574-581.
16. X. P. Huang and T. Moan, Improved modeling of the effect of R-ratio on crack growth rate, Int. J. Fatigue, 29 (2007) 591-602. https://doi.org/10.1016/j.ijfatigue.2006.07.014

17. X. P. Huang, T. Moan, and W. C. Cui, An engineering model of fatigue crack growth under variable, Int. J. Fatigue, 30 (2008) 2-10. https://doi.org/10.1016/j.ijfatigue.2007.03.004

18. M. S. Lee and M. H. Kim, Fatigue crack growth model considering underload history for storm loads, Int. J. Naval Archt. Ocean Eng.(under review for publish) (2022).

19. T. R. Porter, Method of analysis and prediction for variable amplitude, Eng. Fract. Mech. 4 (1972). https://doi.org/10.1016/0013-7944(72)90011-2

20. Hyundai Heavy Industries, Hyundai Heavy Industries Quality Manual, Hyundai Heavy Industries, (2020).

21. IIW-XIII-1235-87, A Review of Japanese Research into the Fatigue of A5083 Alloy Construction for LNG Spherical Tanks, IIW (1987) 1-38.

22. BS8118, Structural use of aluminum, British Standards (1991).

23. H. Tada, P. C. Paris, and G. Irwin, The analysis of cracks handbook, ASME Press, (2000).

24. X. Yan, X. P. Huang, Y. G. Huang, and W. C. Cui, Prediction of fatigue crack growth in a ship detail under wave-induced loading, Ocean Eng. 113 (2016) 246-254. https://doi.org/10.1016/j.oceaneng.2015.10.056

25. M. Toyosada, K. Gotoh, and T. Niwa, Fatigue crack propagation for a through thickness crack: a crack propagation law considering cyclic plasticity near the crack tip, Int. J. Fatigue, 26 (2004) 983-992. https://doi.org/10.1016/j.ijfatigue.2003.12.006

26. R. I. Stephens, D. K. Chen, and B. W. Hom, Fatigue crack growth with negative stress ratio following single overloads in 2024-T3 and 7075-T6 aluminium alloys, ASTM STP, 595 (1976) 172-183. https://doi.org/10.1520/stp33361s

27. D. S. Dawicke, Overload and underload effects on the fatigue crack growth behavior of the 2024-T3 aluminum alloy, NASA CR-201668, (1997). 


\title{
Stress Ratio 및 Load History 효과를 고려한 IMO Type B Spherical LNG Cargo Tank 피로 균열진전 평가
}

\author{
Fatigue Crack Growth Evaluation of IMO Type B Spherical LNG Cargo Tank \\ Considering the Effect of Stress Ratio and Load History
}

\author{
이 명 섭****김 명 현* \\ *부산대학교 조선해양공학과 \\ **현대중공업
}

\section{1. 서 론}

최근 환경 문제로 인해 천연가스는 황산화물, 질소산 화물 및 이산화탄소의 배출을 저감할 수 있는 수소, 암 모니아 등 그린에너지로 전환되는 중간 단계의 친환경 연료로 각광받고 있다. 천연가스는 이송 효율을 높이기 위해 $1 / 600$ 로 부피를 줄일 수 있는 액체 형태의 $\mathrm{LNG}$ (Liquefied Natural Gas)로 이송된다. 천연가스를 액 화시키기 위해 대기압 상태에서 -163 도를 유지하게 되 는데, 이러한 극저온의 위험 화물을 이송하기 위해 IMO IGC Code ${ }^{1)}$ 에 따라 LNG 화물창은 설계되어야 한다.

$\mathrm{IMO}$ 에서는 Fig. 1과 같이 화물창을 선체 구조와의 거동 연결 정도에 따라 크게 독립형 탱크(Independent Tank)와 일체형 탱크(Integrated Tank) 타입으로 분류하고 있다. 또한, 독립형 탱크들은 운항중 1 차 방 벽이 손상되었을 때 가까운 항구로 이동하는 15 일 동안 $\mathrm{LNG}$ 를 저장할 수 있는 2차 방벽의 형태에 따라 Type $\mathrm{A}, \mathrm{B}, \mathrm{C}$ 탱크로 나뉘어진다. 본 연구의 대상인 Type $\mathrm{B}$ 탱크에 대해서는 마지막에 설명하기로 하고, Type A 탱크의 경우 완전한 2차 방벽(Full Secondary Barrier)을 갖추어야 하며 탱크를 둘러싼 선체 구조가 2차 방벽으로 활용되며 저온에 견딜 수 있는 재료로 건조되어야 한다. 통상 $\mathrm{LPG}$ (Liquefied Petroleum

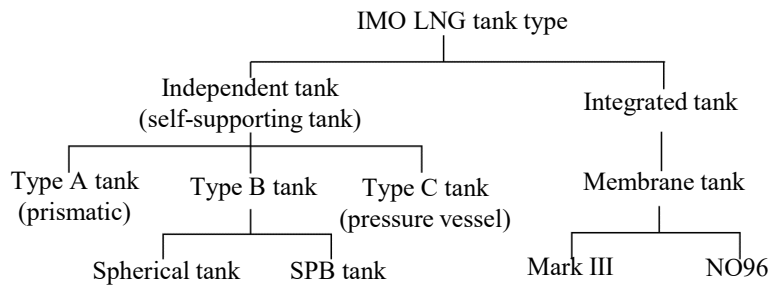

Fig. 1 IMO classification of LNG containment system
Gas) 운반선과 같이 선체가 비교적 높은 온도(-55도) 에 노출되는 선박에 적용되고 있다. Type C 탱크의 2 차 방벽이 필요 없도록(No Secondary Barrier) 설계 압력의 증가와 생산 단계에서 내압시험 및 비파괴시험 을 통해 높은 안전성을 확보하여야 한다. 일반적으로 높은 압력을 견디기 위해 Cylindrical 또는 Bi-Lobe 형태의 압력용기가 대표적이다. 일체형 탱크는 선체구 조에 직접 연결(Mastic Bonding)되어, 선체 거동과 내 부 LNG 하중을 견딜 수 있도록 얇은 막(Membrane) 형태의 1, 2차 방벽으로 구성되고 GTT사의 Mark III 와 NO96 시스템이 대표적이다.

본 연구의 대상이 되는 Type B 탱크는 Drip Tray 라는 부분 2차 방벽(Partial Secondary Barrier)을 갖추고 있다. Type B 탱크에 부분 2차 방벽을 허용하 는 이유는 탱크에 대한 광범위한 해석을 통해 'Leak Before Failure' 개념을 적용하기 때문이다 ${ }^{2,3)}$. 즉, Type B 탱크는 피로해석 및 피로 균열진전(FCG, Fatigue Crack Growth) 해석을 통해 피로 파괴가 일어나지 않아야 하며, 만약 피로 균열이 일어나더라도 피로 균열 부를 통해 누출된 $\mathrm{LNG}$ 가 탱크와 보온재 사 이의 유로(Leakage Path)를 통하여 Drip Tray로 모 여 지고, Drip Tray는 15일 동안 누출된 $\mathrm{LNG}$ 를 저 장할 수 있는 크기로 설계되어 선박의 안전에는 문제가 없어야 한다. Type B 탱크는 높은 강도, 신뢰도와 함 께 화물을 부분 적재(Partial Filling)할 때 발생하는 Sloshing 문제도 없어 $\mathrm{LNG}$ 운반선 뿐만 아니라 $\mathrm{LNG}$ 연료 탱크로도 활용된다 ${ }^{4}$.

본 논문은 Type $\mathrm{B}$ 탱크 중 국내에서 다수 건조된 구형 (Spherical) 탱크의 균열진전에 관한 연구로서 다 양한 균열진전해석 모델을 이용하여 응력비(Stress Ratio)와 하중이력(Load History)의 영향에 대해 살 펴보았다. 


\section{LNG 탱크 강도 평가}

\subsection{K급 LNG 운반선 개요}

구형 IMO Type B LNG 탱크의 균열진전 해석에 사용된 $150 \mathrm{~K}$ 급 $\mathrm{LNG}$ 운반선의 주요 제원을 Table 1 에 나타내었다.

해당 LNG 운반선에는 Fig. 2과 같이 4개의 동일 크기의 화물 탱크가 배치되어 있고, 탱크를 감싸고 있 는 단열 판넬(Tank Insulation Panel), 탱크와 보온 재를 둘러싸고 있는 탱크 Cover, $\mathrm{LNG}$ 펌프와 파이프 라인들이 설치되어 있는 Pump Tower, 탱크의 적도부 (Equator)를 선체와 연결해 주는 Skirt 및 Foundation Deck, 그리고 누출된 LNG를 담아 두는 Drip Tray로 구성된다. 각 탱크는 수직 위치에 따라 적도부 를 포함하여 두께가 다른 8개의 Zone으로 구성된다.

\subsection{LNG 탱크 강도 평가 절차}

구형 LNG 탱크의 균열진전에 적용될 응력을 산출하 기 위해 탱크 강도평가가 선행되어야 하며 몇 가지 해 석 절차를 거치게 된다. 먼저 다양한 화물 적재 상태에 대한 유체해석(Hydrodynamic Analysis)을 통해 Wave 하중과 각 탱크의 가속도를 계산하여 탱크 구조 해석에 적용한다. 탱크 구조해석에 적용되는 하중에는

Table 1 Ship principal dimensions

\begin{tabular}{|c|c|}
\hline Item & Dimension (m) \\
\hline Length & 277 \\
\hline Breadth & 48.9 \\
\hline Depth & 23.35 \\
\hline
\end{tabular}

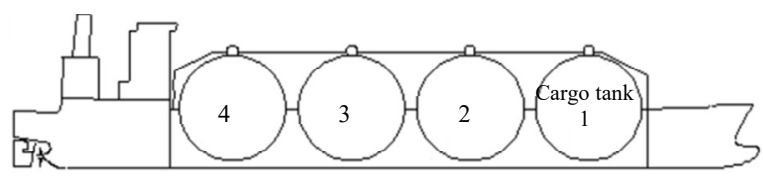

(a) Hull profile configuration ${ }^{5)}$

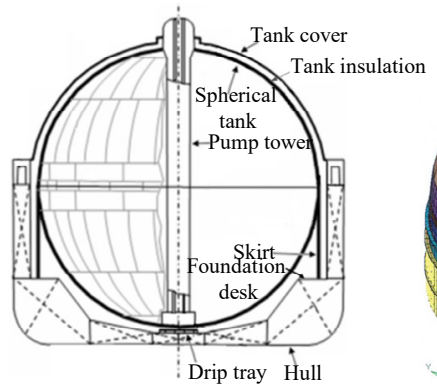

(b) Hull section configuration ${ }^{5)}$

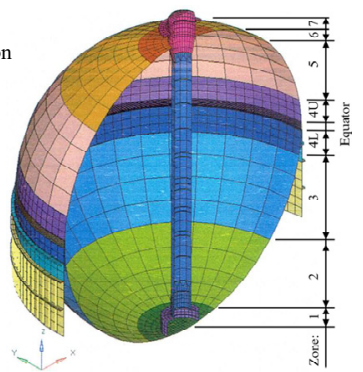

(c) Tank zone
Fig. 2 Hull profile, section and tank zone configuration

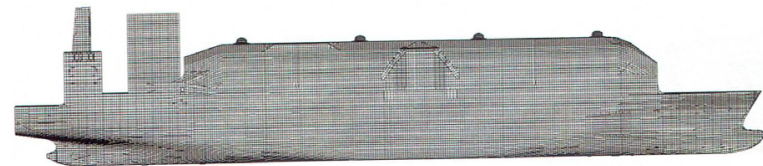

(a) Full ship FEA model

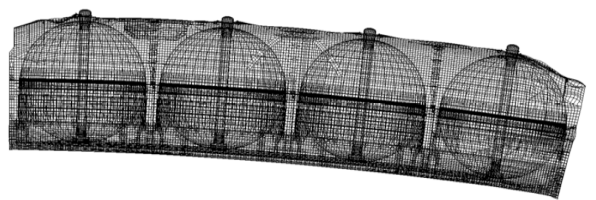

(b) Cargo hold deformed shape by vertical hogging bending moment $^{5)}$

Fig. 3 Full ship FEA model and cargo hold deformed shape by vertical hogging bending moment

$\mathrm{LNG}$ 를 포함한 적재 화물 및 선체 자중에 의한 정적 (Static)/동적(Dynamic) 하중, 내/외부 기체 압력(Vapor Pressure), 극저온의 LNG와 상온의 외기 온도차이에 의한 열분포 및 열응력, 그리고 선체 연동 하중(Hull Interaction Load) 등이 있다. 항복 및 좌굴 강도 평 가를 통해 탱크의 두께가 결정되면, 탱크와 Skirt 또는 Pump Tower 연결부등에 대한 상세 해석(Fine Mesh Analysis), Skirt부 좌굴 강도 평가, Sloshing을 고려 한 Pump Tower 강도 평가, 균열 초기 수명을 평가하 기 위한 피로해석, 균열의 진전 속도를 계산하기 위한 균열진전 해석등이 수행되고 마지막으로 LNG Leak Rate를 계산하여 Drip Tray의 크기를 결정한달. Fig. 3에 해석에 사용된 전선 유한요소해석(FEA) 모델 과 Hull Girder Bending Moment에 의한 화물창 구 역의 변위 형상을 나타내었다.

\section{3. 피로 균열진전 해석 및 모델 비교}

\section{1 피로 균열진전 일반}

일반적으로 Fig. 4 와 같이 응력확대계수 $(\Delta \mathrm{K})$ 와 균열 진전 속도 $(\mathrm{da} / \mathrm{dN})$ 의 관계로 나타나는 균열진전 거동을 평가하기 위해 식 (1)과 같은 Paris 모델을 이용한다.

$$
\frac{d a}{d N}=C(\triangle K)^{m}
$$

여기서, $\mathrm{a}$ 는 균열크기, $\mathrm{N}$ 은 하중횟수, $\mathrm{C}$ 와 $\mathrm{m}$ 은 재료 상수이다.

$\mathrm{LR}^{2)}, \mathrm{DNV}^{3)}$ 와 같은 선급들은 식 (2)와 같이 응력 확대계수 $(\Delta \mathrm{K})$ 를 산출하기 위해 British Standard $\mathrm{BS} 7910^{7)}$ 을 따르고 있으며, BS7910에서는 식 (3)과 같이 타원형 표면 결함의 $(\mathrm{Y} \Delta \sigma)$ 를 계산하기 위해 면내 응력(Membrane Stress)과 면외 응력(Bending Stress) 


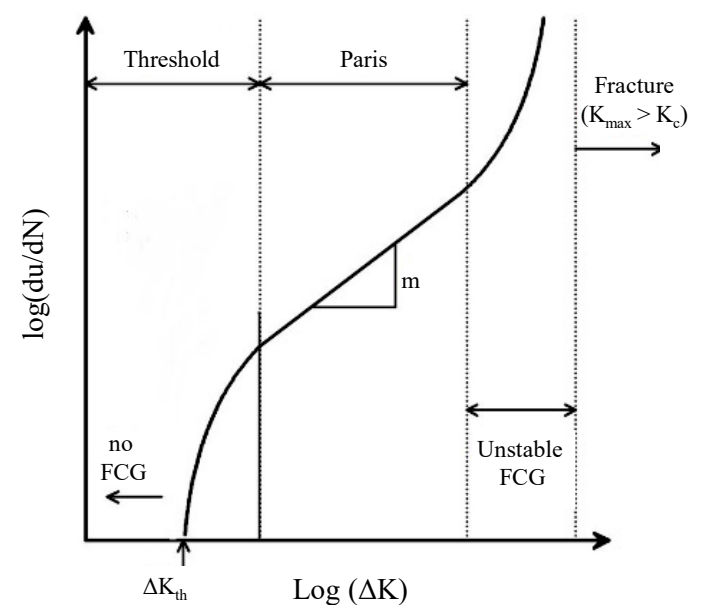

Fig. 4 Schematic of typical FCG data $\left.{ }^{6}\right)$

의 조합을 고려하는 Newman-Raju 방법 ${ }^{8)}$ 을 이용하 고 있다.

$$
\begin{aligned}
& \triangle K=Y \triangle \sigma \sqrt{\pi a} \\
& Y \triangle \sigma=\left[M_{k m} \triangle \sigma_{m}+H M_{k b} \triangle \sigma_{b}\right] F / \varnothing
\end{aligned}
$$

여기서, $\mathrm{Y}$ 는 형상 함수, $\Delta \sigma$ 는 응력 진폭, $\Delta \sigma_{\mathrm{m}}$ 은 면내 응력 진폭, $\Delta \sigma_{\mathrm{b}}$ 는 면외 응력 진폭, $\mathrm{M}_{\mathrm{km}}$ 와 $\mathrm{M}_{\mathrm{kb}}$ 는 각각 용접 Toe부 면내 및 면외 응력 집중계수, $\mathrm{H}$ 는 면내 응력과 면외 응력 집중계수의 비율, $\mathrm{F}$ 는 균열 형상 및 두 께의 함수이고 $\phi$ 는 균열 형상에 대한 타원 함수이다 ${ }^{7}$

\section{2 피로 균열진전 모델}

Paris 모델의 경우 실제 구조물에 부가되는 다양한 응력비와 하중이력을 고려하지 않아 실제 균열진전 현 상을 반영하지 못하고 있기 때문에 다양한 균열진전 모 델들이 제안되어왔다.

먼저, 최대 응력과 최소 응력 비율을 나타내는 응력비 (Stress Ratio, R)를 고려한 모델들을 살펴보면 아래와 같담. Walker ${ }^{10)}$, Eason et al. ${ }^{11)}$ 및 Kurihara et $\mathrm{al}^{12)}$ 등은 식 (4)와 같이 응력비를 $\triangle K_{\text {eff }}=f(R) \triangle K$ 또 는 $\triangle K_{e f f}=K_{\max }^{(1-r)} \triangle K^{r}$ 과 같은 형태로 표현하여 응력비가 증가할 때 균열진전이 가속화 되는 현상을 반영하였다.

$$
\frac{d a}{d N}=\frac{C_{0}}{(1-R)^{m(1-r)}}(\triangle K)^{m}
$$

여기서, $r$ 은 재료상수이다.

Forman ${ }^{13)}$ 과 McEvily and Gregor ${ }^{14)}$ 는 식 (5)와 같이 Paris 모델에 Fracture Toughness $\left(\mathrm{K}_{\mathrm{C}}\right)$ 또는 Maximum Stress Intensity Factor $\left(\mathrm{K}_{\max }\right)$ 등을 추 가하였고 ${ }^{9)}$, 두번째 식을 살펴보면 $\mathrm{K}_{\max }$ 값이 $\mathrm{K}_{\mathrm{c}}$ 에 가 까워질수록 균열진전 속도가 증가함을 알 수 있다 ${ }^{15)}$.

$$
\frac{d a}{d N}=\frac{C(\Delta K)^{m}}{(1-R) K_{c}-\Delta K}=\frac{C(\Delta K)^{m}}{(1-R)\left(K_{c}-K_{\max }\right)}
$$

한편, Huang and $\mathrm{Moan}^{16)}$ 은 응력비가 다른 시험결 과에서 나타나는 다양한 응력확대계수 값들을 $R=0$ 의 시험결과로 조정하여 식 (6)과 같은 모델과 식 (7)에 서와 같이 응력비 수정 계수 $\left(\mathrm{M}_{\mathrm{R}}\right)$ 와 Overload에 의해 균열진전이 지연되는 현상을 설명하는 소성영역 크기 수정계수 $\left(\mathrm{M}_{\mathrm{P}}\right)$ 를 동시에 고려한 모델을 제안 하였다 ${ }^{17)}$.

$$
\begin{aligned}
& \frac{d a}{d N}=\left[\left(\Delta K_{e q 0}\right)^{m}-\left(\Delta K_{t h 0}\right)^{m}\right] \\
& \Delta K_{e q 0}=M_{R} M_{P} \Delta K
\end{aligned}
$$

Lee and $\mathrm{Kim}^{18)}$ 은 Huang 모델에 기반하여 Port의 실험식 ${ }^{19)}$ 을 이용하여 Overload 뿐만 아니라 Underload 를 함께 고려할 수 있는 식 (11)과 같은 하중이력 수 정계수 $\left(\mathrm{M}_{\mathrm{H}}\right)$ 를 도입하여 식 (8)과 같은 균열진전 모델 을 제안하였다. 이 모델은 문헌에 나타난 다양한 시험 과 비교를 통하여, 식 오류! 참조 원본을 찾을 수 없습 니다. 와 같이 응력비 수정 계수 $\left(\mathrm{M}_{\mathrm{R}}\right)$ 와 하중이력 수정 계수 $\left(\mathrm{M}_{\mathrm{H}}\right)$ 에 대한 지수 형태의 가중치를 적용하였다.

$$
\begin{aligned}
& \frac{d a}{d N}=C\left(\Delta K_{e q}\right)^{m} \\
& \Delta K_{e q}=M_{R}^{1.1} M_{H}^{0.9} \Delta K \\
& M_{R}=\left\{\begin{array}{cc}
\left(1-R_{1}\right)^{-\beta_{1}} & \left(-5 \leq R_{1}<0\right) \\
\left(1-R_{1}\right)^{-\beta} & \left(0 \leq R_{1}<0.5\right) \\
\left(1.05-1.4 R_{1}+0.6 R_{1)^{-\beta}}^{2}\right. & \left(0.5 \leq R_{1}<1\right)
\end{array}\right. \\
& M_{H}=\left(12.65 e^{-2.54 R_{2}}\right)^{1 / m}
\end{aligned}
$$

where,

$$
\begin{aligned}
& R_{1}=\text { Stress ratio } \\
& \begin{aligned}
R_{2} & =\frac{K_{O L}-K_{U L}}{K_{\max }-K_{U L}} \\
\beta & =0.5 \text { for titanium alloy } \\
& =0.7 \text { for aluminum alloys and steels } \\
\beta_{1} & =1.2 \beta
\end{aligned}
\end{aligned}
$$

$\mathrm{K}_{\mathrm{OL}}, \mathrm{K}_{\mathrm{UL}}, \mathrm{K}_{\max }$ : Stress intensity factor for overload, underload and maximum load

\section{3 구형 LNG 탱크 피로 균열진전 해석}

앞서 설명된 $\mathrm{LNG}$ 탱크 강도 평가를 통해 균열진전 평가에 적용된 응력 진폭 및 위치를 Fig. 5에 나타내 었다. 비교적 응력 진폭이 크고 해당 범위가 넓은 Zone 2와 Zone 3사이 용접부의 면내 및 면외 응력 진폭은 각각 $40 \mathrm{MPa}$ 및 $2.5 \mathrm{MPa}$ 로 평가되었고, Full 


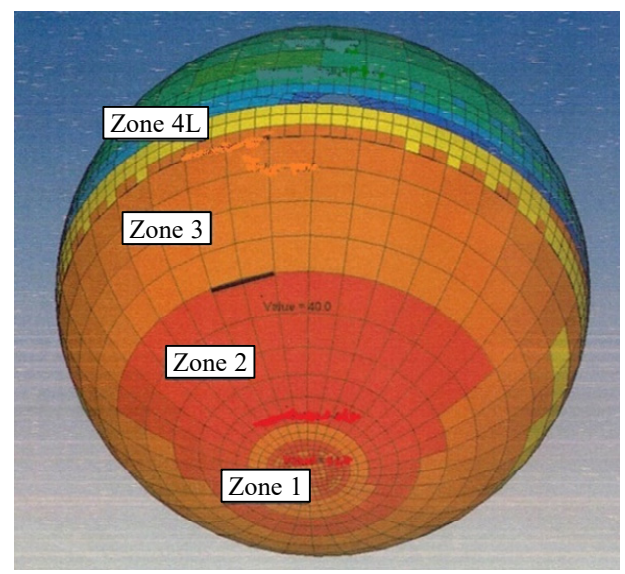

Fig. 5 Stress range of circumferential detail

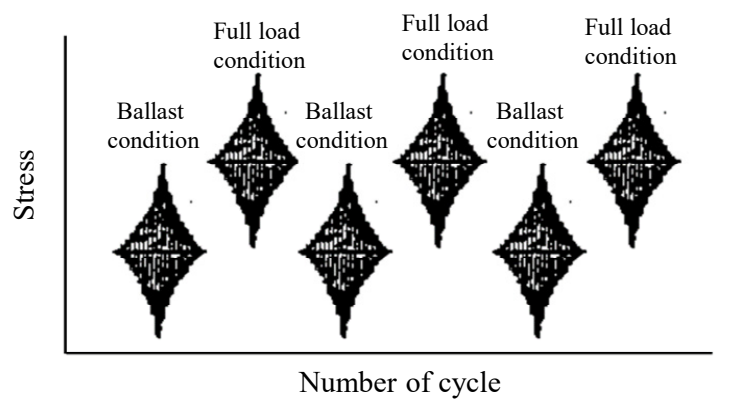

Fig. 6 Schematic diagram of stress

Table 2 Material property for AL5083-O

\begin{tabular}{|c|c|c|}
\hline $\begin{array}{c}\mathrm{C} \\
(\mathrm{mm} / \mathrm{cycle})\end{array}$ & $\begin{array}{c}\mathrm{m} \\
(M P a \sqrt{m m})\end{array}$ & $\begin{array}{c}\text { Kth } \\
\left(M P a ~ m m^{3 / 2}\right)\end{array}$ \\
\hline $1.536 \mathrm{E}-12^{21)}$ & $3.04^{21)}$ & $24.3^{22)}$ \\
\hline
\end{tabular}

Load 및 Ballast 운항조건에서 정적 응력(Static Stress) 은 각각 $42.5 \mathrm{MPa}$ 및 $2.0 \mathrm{MPa}$ 로 계산되었다. 선박 에 작용하는 응력 이력에 대한 개략도를 Fig. 6에 나 타내었다.

초기 표면결함의 크기는 조선소의 비 파괴 검사(NDT) 허용 기준 ${ }^{20}$ 에 따라 깊이(a) $0.5 \mathrm{~mm}$, 길이(2c) $50 \mathrm{~mm}$ 가 적용되었다.

탱크의 건조에 알루미늄 합금 $(5083-\mathrm{O})$ 의 균열진전 관련 재료 물성치를 Table 2에 나타내었다.

응력확대계수 $(\Delta \mathrm{K})$ 를 계산하기 위해 시험을 통한 경험 식을 이용하는 방법 ${ }^{23)}$ 과 해석적 방법 ${ }^{24)}$ 이 있으나, 본 연구에서는 Fig. 7과 같은 표면 결함에 대한 $\mathrm{BS} 7910^{7)}$ Annex M에 따라 식 (3)을 이용하여 계산되었다. 또한, LR Procedure ${ }^{2)}$ Section D12의 건조 공차(Construction Tolerance)에 따른 응력집중 계수를 고려하였다.

본 연구에서는 DNV Guideline ${ }^{3)}$ 에 따라 North Atlantic Wave를 $10^{8}$ 번 조우하는 장기 파도 응력 진
폭 분포(Long Term Wave-Induced Stress Range Spectrum)와 Weibull 분포 형상 함수 $\mathrm{h}$ 를 1.0 으로 가정하여 Fig. 8과 같은 면내 응력 분포를 적용하였다. 또한, 하중이력(Load History)의 변화에 따른 균열진 전의 영향을 살펴보기 위해, Fig. 9과 같이 편도 1 항 차 운항 동안 3 가지 응력 진폭 순서에 노출되는 경우 에 대해 평가해 보았다. Case 1의 경우 운항 중에 연 근해에서는 작은 하중을, 먼 바다에서는 큰 하중을 받 는 일반적인 분포를 가정하였고, Case 2 와 Case 3 은 운항하는 동안 하중이 각각 증가하거나 감소하는 경우 이다. 선박의 수명동안 500 항차를 운항하는 조건으로 한 항차의 응력분포는 $2 \times 10^{5}$ Cycle로 가정하였다.

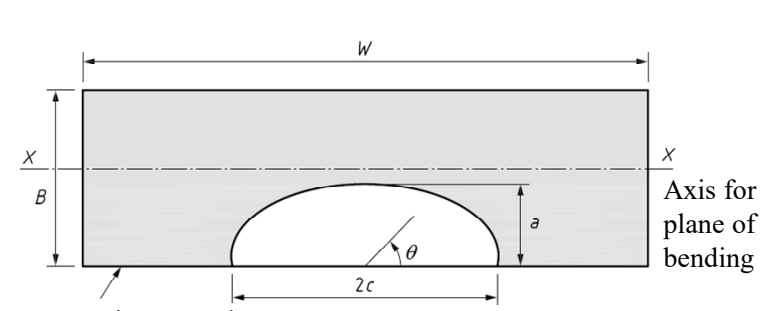

In equations, Maximum tensile bending stress is at this surface

Fig. 7 Surface flaw $^{7)}$

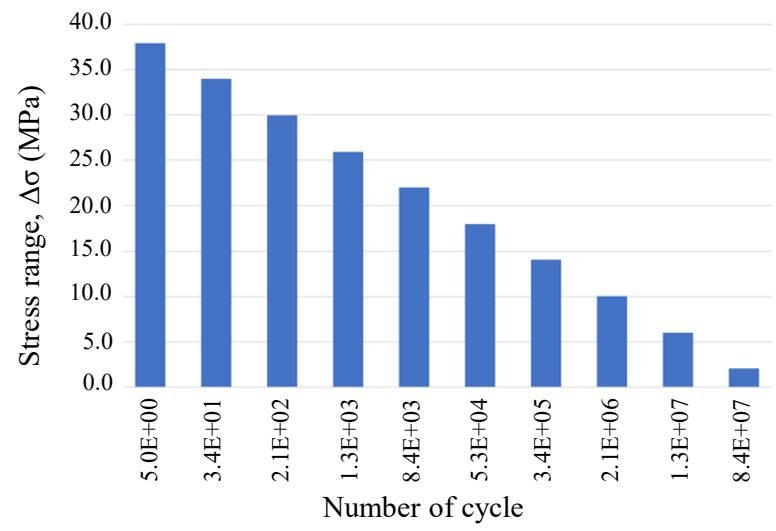

Fig. 8 Long term membrane stress distribution $\left(10^{8}\right.$ cycles $)$

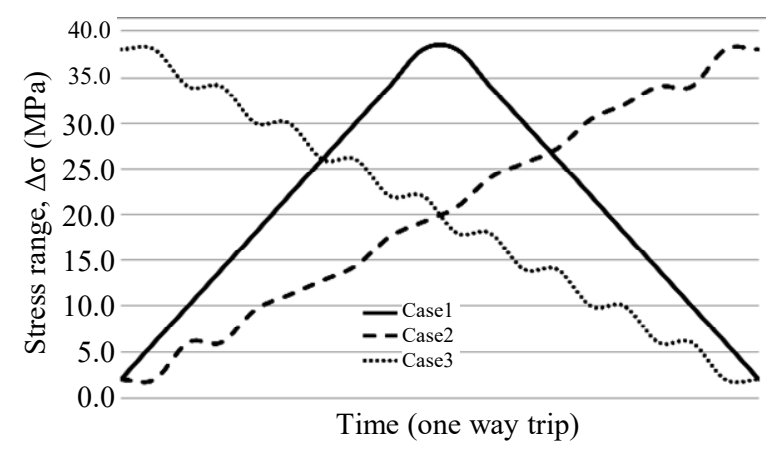

Fig. 9 Membrane stress range history during one way trip $\left(2 \times 10^{5}\right.$ cycles $)$ 


\section{4. 결과 및 고찰}

구형 IMO Type B LNG 탱크에 5가지 균열진전 모델과 3 가지 하중이력을 적용한 결과를 Fig. 10 에 나 타내었다. Forman 모델의 균열 깊이 'a' 값을 보면 $6.0 \mathrm{E}+07$ Cycle에서 균열 깊이 기준 $0.5 \mathrm{t}$ 에 해당하 는 $22.5 \mathrm{~mm}$ 를 넘어가고 있다. 전반적으로 Forman 모델과 Paris 모델은 보수적인 결과를, Huang 모델은

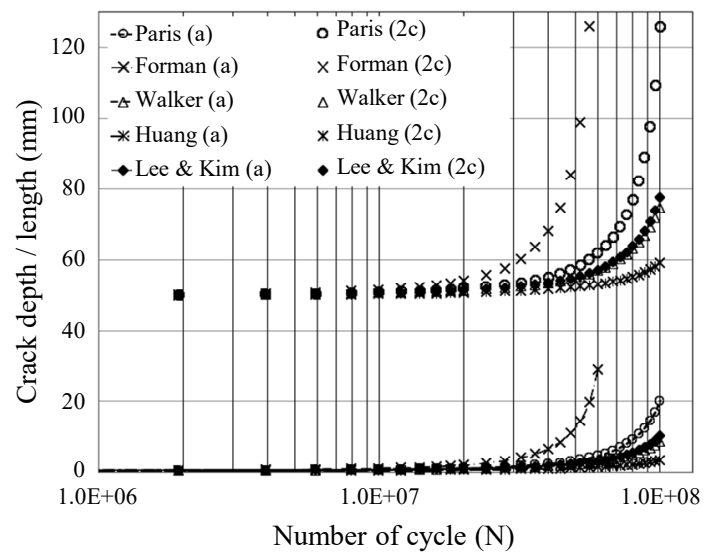

(a) Case 1

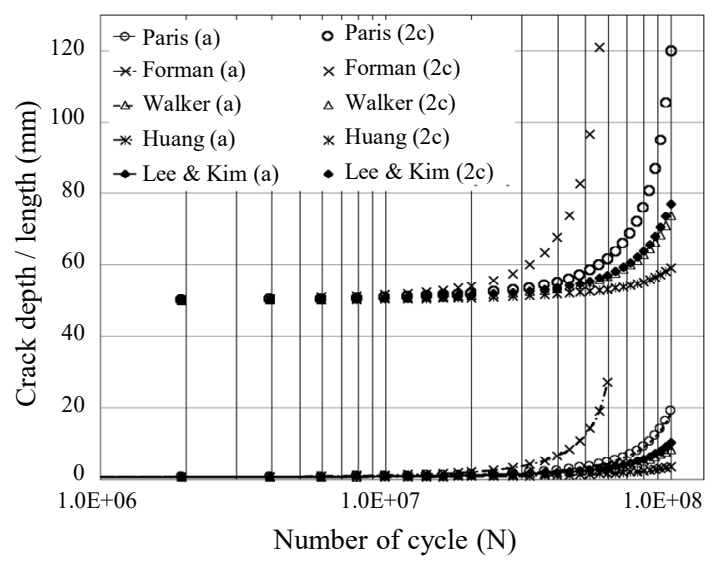

(b) Case 2

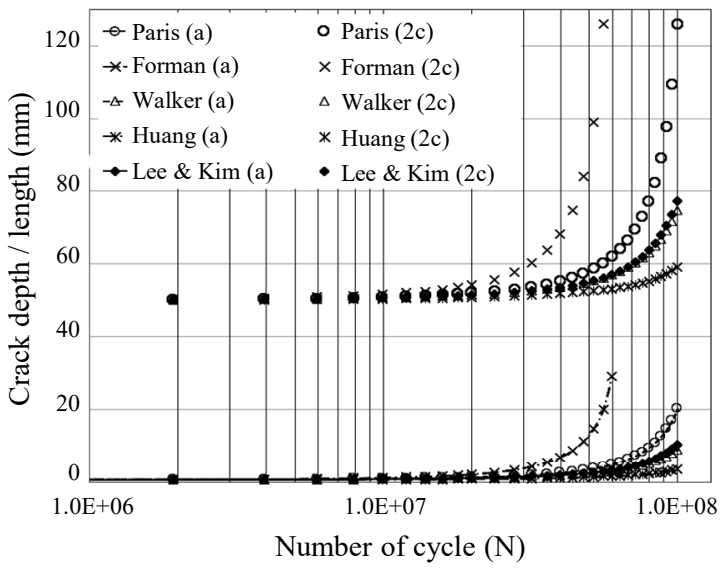

(c) Case 3

Fig. 10 Results of fatigue crack growth for depth ' $a$ ' and length ' $2 c$ '
가장 낙관적인 결과를 보이고 있다. Lee \& Kim 모델 은 Walker 모델과 유사하게 비교적 낙관적인 결과를 나타낸다. Forman 모델과 Walker 모델은 식 (4) 및 식 (5)와 같이 응력비를 고려하는데, Walker 모델의 경우 응력비에 $m$ 을 지수로 사용하기 때문에 Forman 모델에 비해 응력비 증가에 따른 균열 진전 속도를 느 리게 평가하고 있다.

Case 1 의 $1.0 \mathrm{E}+6 \sim 1.0 \mathrm{E}+7$ Cycle에 대한 상세 균열 진전 크기 결과를 Fig. 11에 나타내었다. Paris 모델을 제외한 모든 모델들은 Cycle이 증가함에 따라 균열진전 속도가 계단 형태를 나타내고 있는데, 이는 Full Load시 균열진전 속도 증가와 Ballast 운항조건 에서 균열진전 속도 감소를 나타낸다. 한편 Huang 모 델과 Lee \& Kim 모델의 경우 응력비와 하중이력을 같이 고려하고 있는데, Full Load에서 균열 진전이 가 속화되고 Ballast 운항조건에서 균열 진전이 느려지는 과정 ${ }^{25)}$ 을 확연히 보여주고 있다. Huang 모델의 경우 Lee \& Kim 모델과 달리 과거 하중 이력 중 Overload 이후에 Underload가 부가될 경우 Overload에 의한 균열 지연이 약화되는 현상 26,27$)$ 을 반영하지 못하기 때

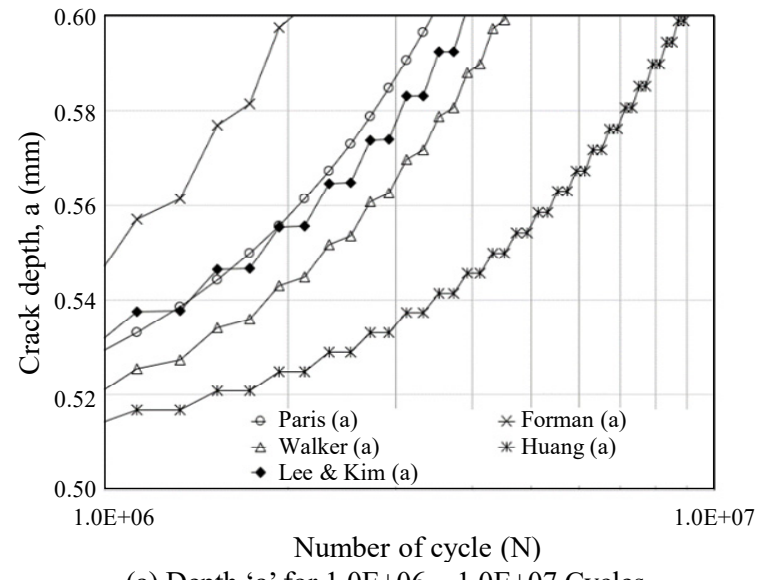

(a) Depth 'a' for 1.0E+06 1.0E+07 Cycles

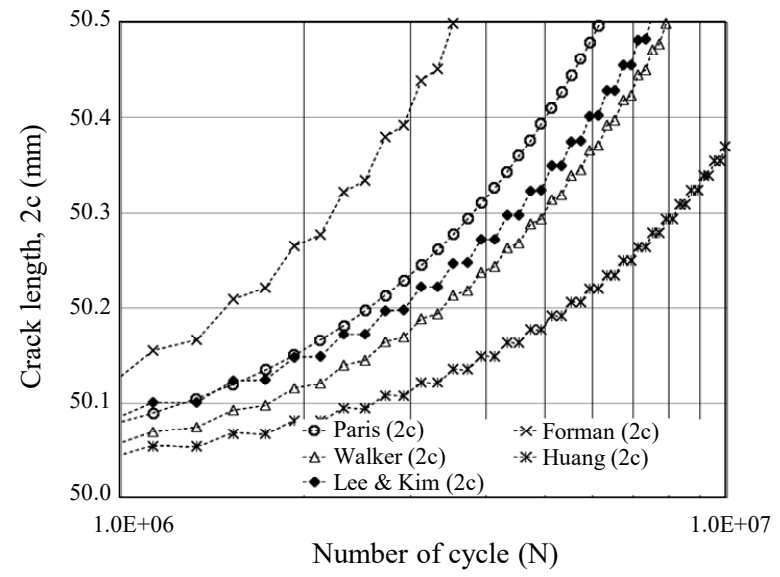

(b) Length ' $2 \mathrm{c}$ ' for $1.0 \mathrm{E}+06 \sim 1.0 \mathrm{E}+07$ Cycles

Fig. 11 Detail results of fatigue crack growth for case 1

본 논문은 독자의 이해를 돕기위하여 영문논문을 국문으로 번역하여 게재한 논문입니다. 저자는 본 논문으로 연구업적과 같은 실적에 중복으로 지원받거나 인정받을 수 없음을 알려드립니다. 


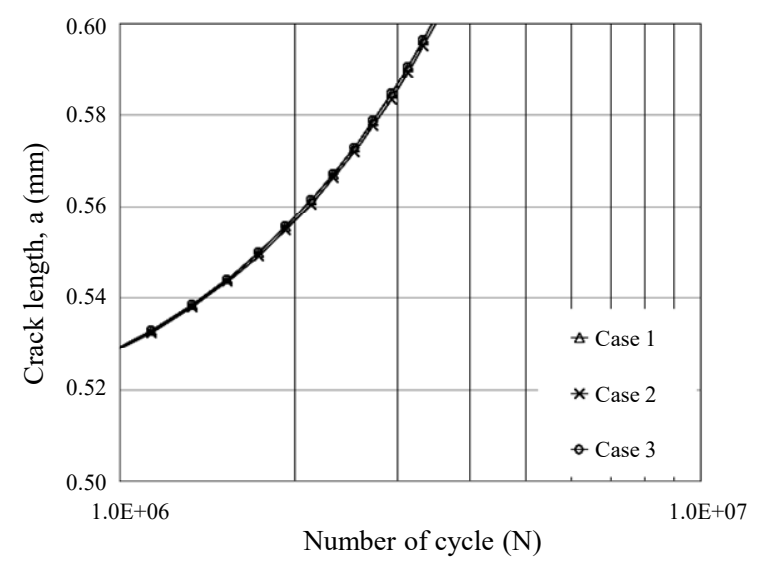

(a) Paris model

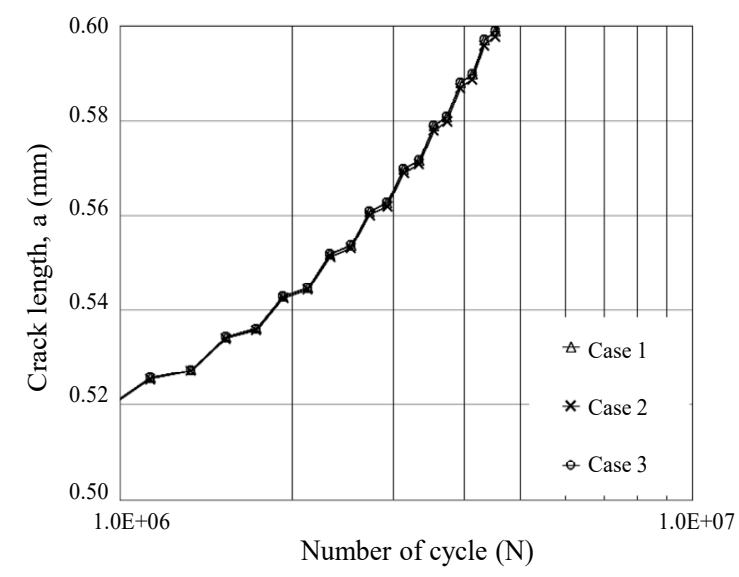

(c) Walker model

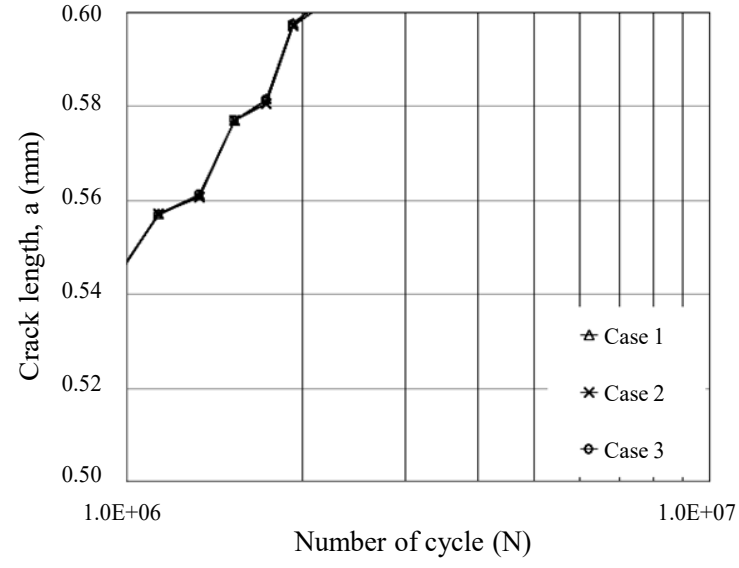

(b) Forman model

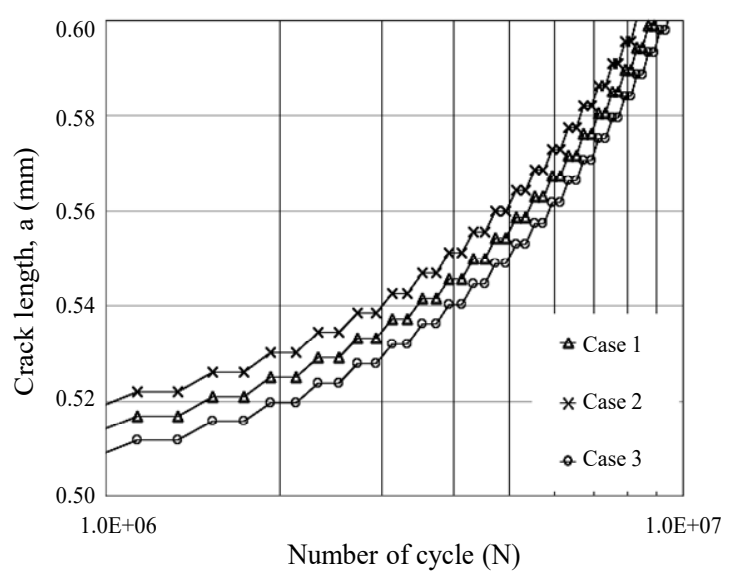

(d) Huang model

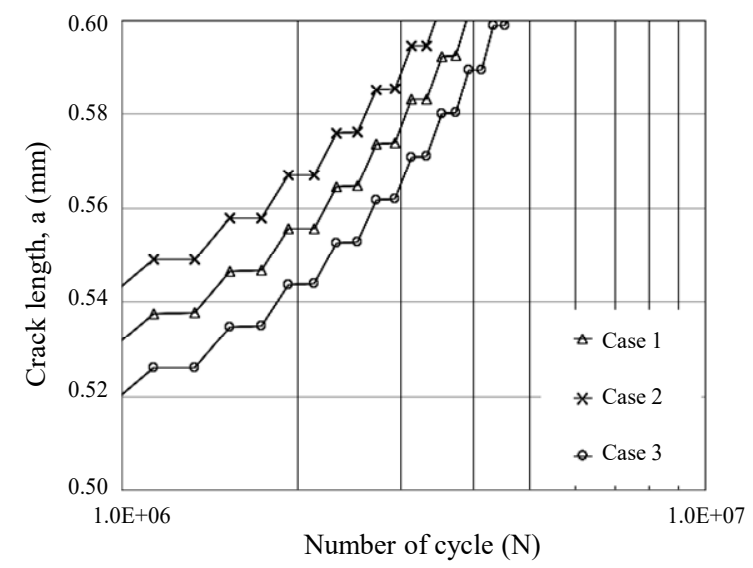

(e) Lee \& Kim model

Fig. 12 Fatigue crack growth of cases $1 \sim 3$ for $1.0 \mathrm{E}+06 \sim 1.0 \mathrm{E}+07$ cycles

문에 Fig. 11 과 같이 균열진전 속도가 가장 낮게 평가 되고 있다.

세 하중 이력 Case에 대한 영향을 비교하기 위해 Fig. 12 에 각 모델 별 균열진전 결과를 나타내었다. Paris, Forman 및 Walker 모델에서는 세 하중 이력 차이에 따른 뚜렷한 변화를 나타내지 않았다. 소성 영역 크기 수정계수 $\left(\mathrm{M}_{\mathrm{P}}\right)$ 를 고려한 Huang 모델이나 하중이력 수
정계수 $\left(\mathrm{M}_{\mathrm{H}}\right)$ 를 도입한 Lee \& Kim 모델에서는 운항 중 하중이 계속 감소하는 Case 3 의 경우 가장 느린 균열진전을 보여주고 있고, Case 2의 경우 가장 빠른 속도를 보여준다. 균열진전 속도는 Overload 하중이 과거에 발생한 확률에 따라 달라지게 되는데, Case 3 의 경우 하중 이력 중 Overload가 항상 존재하므로 균열진전 지연이 지속적으로 발생하게 된다. 


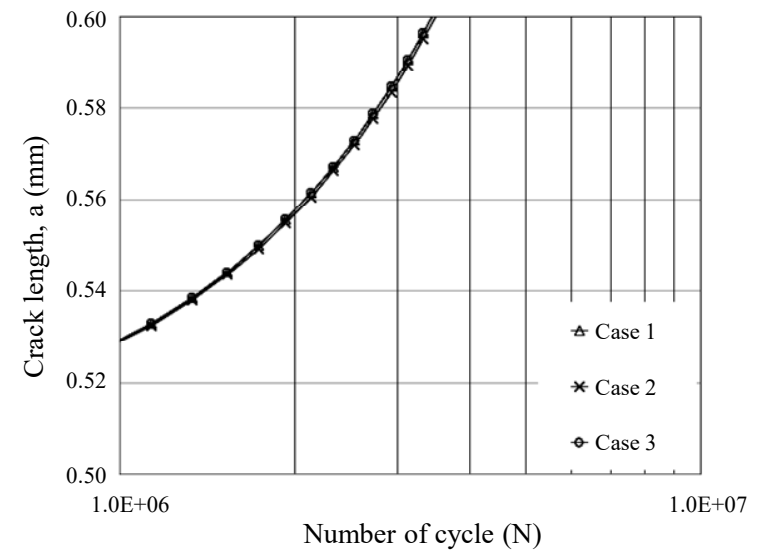

(a) Paris model

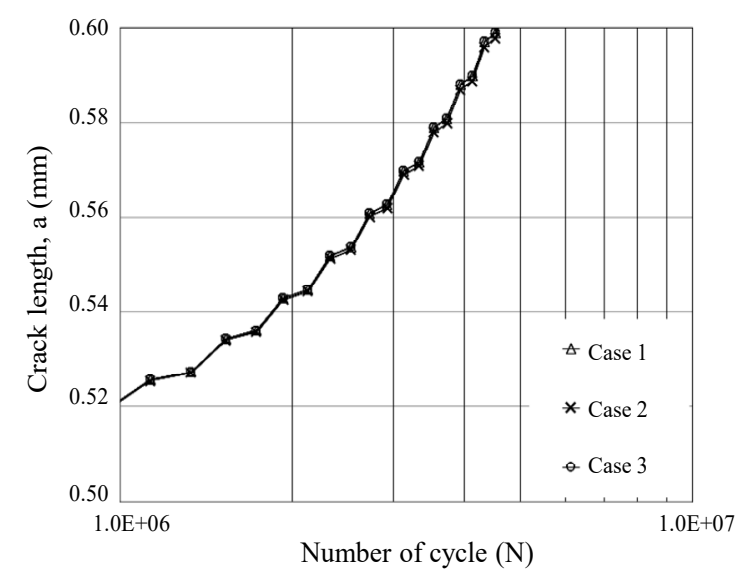

(c) Walker model

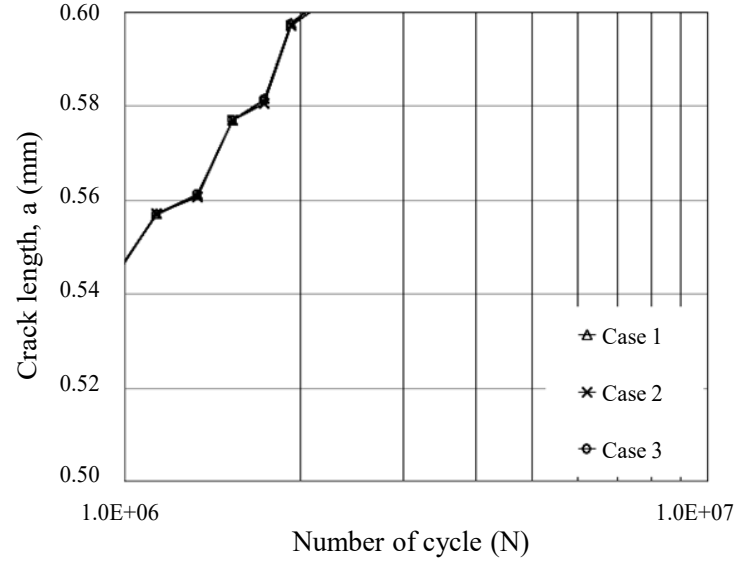

(b) Forman model

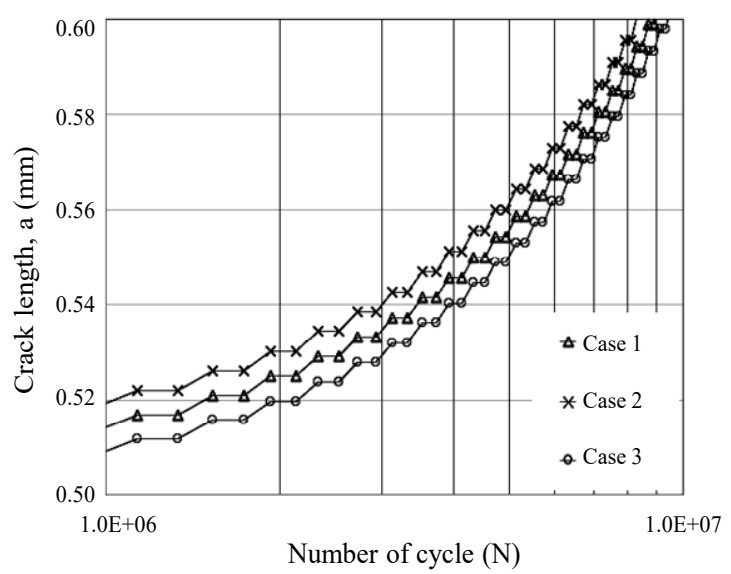

(d) Huang model

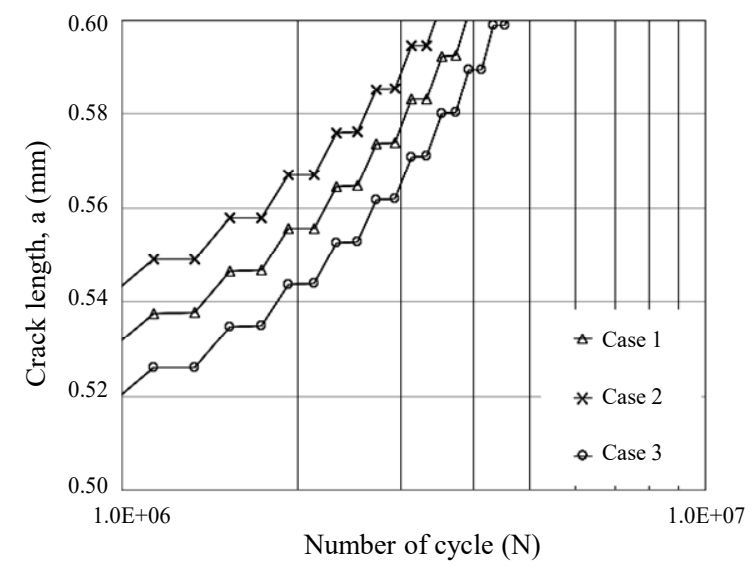

(e) Lee \& Kim model

Fig. 12 Fatigue crack growth of cases $1 \sim 3$ for $1.0 \mathrm{E}+06 \sim 1.0 \mathrm{E}+07$ cycles

\section{5. 결 론}

본 논문은 $150 \mathrm{~K}$ 급 $\mathrm{LNG}$ 운반선에 배치된 구형 (Spherical) IMO Type B LNG 탱크의 균열진전에 관한 연구로서, 다양한 균열진전해석 모델을 이용하여 응력비(Stress Ratio)와 하중이력(Load History)의 영향에 대해 살펴보았다
IMO Type B 탱크의 경우 다양한 해석을 통해 고도 의 안전성을 요구하므로 강도 평가이외에 피로해석, 피 로 균열진전 해석 및 LNG Leak Rate를 계산하여야 한다. 피로 균열진전 해석을 위해 Paris 모델 이외에 다양한 모델들이 제시되고 있고, Forman 모델과 Walker 모델은 응력비를 고려하고 있다. Huang 모델과 Lee \& Kim 모델은 응력비 뿐만 아니라 과거 하중 이력 
중 Overload와 Underload의 존재가 균열진전에 미치 는 영향을 함께 고려하고 있다.

다섯가지 균열진전 모델에 대해 응력비와 하중이력에 의한 영향을 살펴보기 위해, Full Load와 Ballast 운 항조건의 응력과 세가지 응력 진폭 순서 Case를 고려 하여 $\mathrm{LNG}$ 탱크의 피로 균열진전을 평가하였고 아래와 같은 결론을 도출하였다.

1) 보수적인 결과를 보여주는 Paris 모델은 응력비 와 하중이력을 고려하지 않고, 선급 Rule 및 국제 규 격을 통해 실제 선박 설계에 이용되고 있다.

2) 응력비를 고려하는 Forman 및 Walker 모델은 전반적으로 보수적인 결과를 보여주지만 응력비 적용 방법에 따라 결과가 차이 나며, 두 모델 모두 하중 이 력에 대한 영향은 고려하지 않는다.

3) Huang 모델의 경우 합리적인 응력비를 반영하고 있지만, Underload에 의한 Overload의 균열진전 지 연 완화 현상을 반영하고 있지 못하고 있어 낙관적인 결과를 보여주고 있다.

4) Lee \& Kim 모델의 경우 Overload 뿐만 아니 라 Underload에 의한 하중 이력을 고려하며 Paris 모 델과 근접한 결과를 보여주고 있어 실 설계에 적용 가 능하다.

ORCID: Myung-Sup Lee:https://orcid.org/0000-0003-2661-8960 ORCID: Myung-HyunKim:https://orcid.org/0000-0003-4428-6058

\section{References}

1. IMO, The International Code of the Construction and Equipment of Ships Carrying Liquefied Gases in Bulk (IGC Code), Imternational Maritime Organizqation Resolution MSC. 370(93) (2014).

2. LR, Fatigue assessment of ship units adopting IMO Type B independent tanks constructed primarily of plane surfaces for the storage of liquefied gases, Lloyd's Register ShipRight Design and construction, (2014).

3. DNV GL, Liquefied gas carriers with spherical tanks of type B, DNV GL DNVGL-CG-0134 (2018).

4. Y. Nagata, IHI-SPB Tank for LNG-Fueled Ship, IHI Engineering Review, 2 (2015).

5. U. N. Kim, A Study on the Buckling Strength of the Skirt Structure in the Spherical LNG Carriers, J. Soc. Naval Archit. Korea, 54 (2017) 393-405. https://doi.org/10.3744/SNAK.2017.54.5.393

6. J. A. Newman, The Effects of Load Ratio on Threshold Fatigue Crack Growth of Aluminum Alloys, Virginiatech Doctor Dissertation, (2000).

7. BS7910, Guide to methods for assessing the acceptability of flaws in metallic structures, British Standards, (2013).
8. J. C. Newman Jr and I. S. Faju, Analyses of surface cracks in finite plates under tension or bending loads, NASA Technical Report, 1578 (1979).

9. A. Chahardehi and A. Mehmanparast, Fatigue crack growth under remote and local compression - a state-of- the-art review, Frattura ed Integrità Strutturale, 35 (2016) 41-49. https://doi.org/10.3221/IGF-ESIS.35.05

10. K. Walker, The effect of stress ratio during crack propagation and fatigue for 2024-T3 and 7075-T6 aluminum, ASTM STP462, (1970).

11. E. D. Eason, J. D. Gilman, D. P. Jones, and S. P. Andrew, Technical basis for a revised fatigue crack growth rate reference curve for ferritic steels in air, J. Press. Vessel Technol. 114 (1992) 80-86. https://doi.org/10.1115/1.2929016

12. M. Kurihara, A. Katoh, and M. Kawahara, Effects of stress ratio and step loading on fatigue crack propagation rate, Soc. Mater. Sci. 1 (1985) 217-233.

13. R. G. Forman, Study of fatigue crack initiation from flaws using fracture mechanics theory, Eng. Fract. Mech. 4 (1972) 333-345. https://doi.org/10.1016/0013-7944(72)90048-3

14. A. J. McEvily and J. Gregor, On the threshold for fatigue-crack growth, 4th International Conference of Fracture, Waterloo, 2 (1977) 1293-1298.

15. N. E. Dowling, Mechanical Behavior of Materials, Pearson, (2013) 574-581.

16. X. P. Huang and T. Moan, Improved modeling of the effect of R-ratio on crack growth rate, Int. J. Fatigue, 29 (2007) 591-602. https://doi.org/10.1016/j.ijfatigue.2006.07.014

17. X. P. Huang, T. Moan, and W. C. Cui, An engineering model of fatigue crack growth under variable, Int. J. Fatigue, 30 (2008) 2-10. https://doi.org/10.1016/j.ijfatigue.2007.03.004

18. M. S. Lee and M. H. Kim, Fatigue crack growth model considering underload history for storm loads, Int. J. Naval Archt. Ocean Eng.(under review for publish) (2022).

19. T. R. Porter, Method of analysis and prediction for variable amplitude, Eng. Fract. Mech. 4 (1972). https://doi.org/10.1016/0013-7944(72)90011-2

20. Hyundai Heavy Industries, Hyundai Heavy Industries Quality Manual, Hyundai Heavy Industries, (2020).

21. IIW-XIII-1235-87, A Review of Japanese Research into the Fatigue of A5083 Alloy Construction for LNG Spherical Tanks, $I I W$ (1987) 1-38.

22. BS8118, Structural use of aluminum, British Standards (1991).

23. H. Tada, P. C. Paris, and G. Irwin, The analysis of cracks handbook, ASME Press, (2000).

24. X. Yan, X. P. Huang, Y. G. Huang, and W. C. Cui, Prediction of fatigue crack growth in a ship detail under 
wave-induced loading, Ocean Eng. 113 (2016) 246-254. https://doi.org/10.1016/j.oceaneng.2015.10.056

25. M. Toyosada, K. Gotoh, and T. Niwa, Fatigue crack propagation for a through thickness crack: a crack propagation law considering cyclic plasticity near the crack tip, Int. J. Fatigue, 26 (2004) 983-992. https://doi.org/10.1016/j.ijfatigue.2003.12.006
26. R. I. Stephens, D. K. Chen, and B. W. Hom, Fatigue crack growth with negative stress ratio following single overloads in 2024-T3 and 7075-T6 aluminium alloys, ASTM STP, 595 (1976) 172-183. https://doi.org/10.1520/stp33361s

27. D. S. Dawicke, Overload and underload effects on the fatigue crack growth behavior of the 2024-T3 aluminum alloy, NASA CR-201668, (1997). 